In cooperation with the Houston-Galveston Area Council

\title{
Influence of Stream Habitat and Land Use on Benthic Macroinvertebrate Indicators of Stream Quality of Selected Above-Tidal Streams in the Houston-Galveston Area Council Service Area, Texas, 1997-98
}

Water-Resources Investigations Report 01-4010 


\section{Cover:}

Buffalo Bayou west of downtown Houston. (Photograph by J. Bruce Moring, August 1998.) 
U.S. Department of the Interior

U.S. Geological Survey

\section{Influence of Stream Habitat and Land Use on Benthic Macroinvertebrate Indicators of Stream Quality of Selected Above-Tidal Streams in the Houston-Galveston Area Council Service Area, Texas, 1997-98}

By J. Bruce Moring

U.S. GEOLOGICAL SURVEY

Water-Resources Investigations Report 01-4010

In cooperation with the Houston-Galveston Area Council 


\section{U.S. DEPARTMENT OF THE INTERIOR}

Gale A. Norton, Secretary

\section{U.S. GEOLOGICAL SURVEY}

Charles G. Groat, Director

Any use of trade, product, or firm names is for descriptive purposes only and does not imply endorsement by the U.S. Government.

For additional information write to

\section{District Chief}

U.S. Geological Survey

8027 Exchange Dr.

Austin, TX 78754-4733

E-mail: dc_tx@usgs.gov

Copies of this report can be purchased from

U.S. Geological Survey

Branch of Information Services

Box 25286

Denver, CO 80225-0286

E-mail: infoservices@usgs.gov 


\section{CONTENTS}

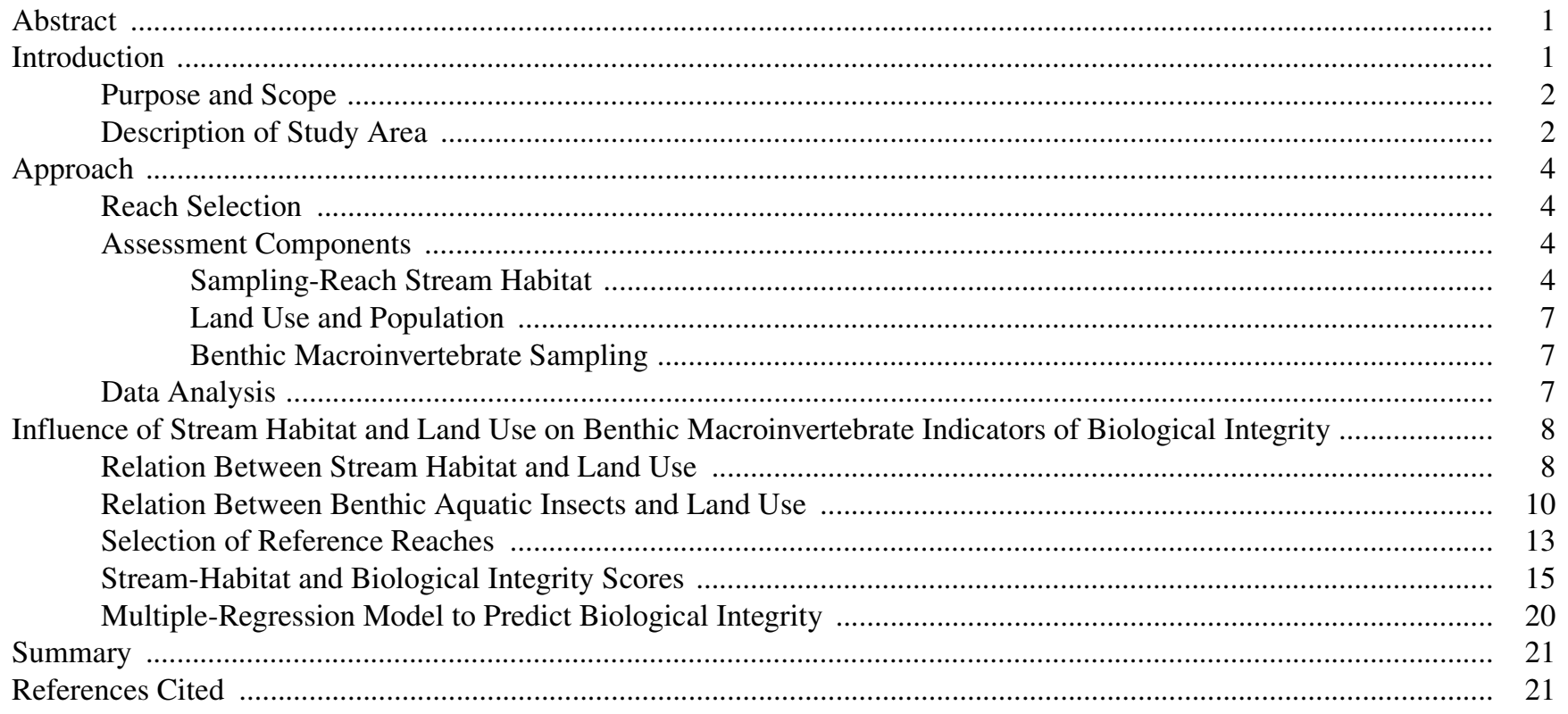

\section{FIGURES}

1. Map showing data-collection sites in the Houston-Galveston Area Council service area .................................

2. Boxplots showing distribution of selected stream-habitat variables for reaches grouped by dominant land use

3. Graphs showing relation between population density in above-reach drainage areas and selected stream-habitat variables

4. Boxplots showing distribution of selected benthic aquatic insect variables for reaches grouped by dominant land use

5-10. Graphs showing:

5. Relation between population density in above-reach drainage areas and selected benthic aquatic insect variables

6 Reach structural index and RCE maximum for selected reaches classified by percentile and stream-habitat integrity score.

7. Percent EPT taxa and number of taxa for selected reaches classified by percentile and biological integrity score 3 5 20 21 
5. Factor loadings from principle components analysis (PCA) greater than 0.7 for land-use variables and proportion of variation explained by each principal component .......

6. Factor loadings from principle components analysis (PCA) greater than 0.7 for benthic aquatic insect variables and proportion of variation explained by each principal component

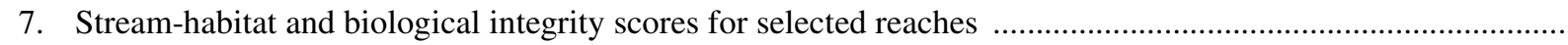




\section{Influence of Stream Habitat and Land Use on Benthic Macroinvertebrate Indicators of Stream Quality of Selected Above-Tidal Streams in the Houston-Galveston Area Council Service Area, Texas, 1997-98}

\section{By J. Bruce Moring}

\section{Abstract}

During 1997-98, the U.S. Geological Survey, in cooperation with the Houston-Galveston Area Council, collected stream-habitat and benthic macroinvertebrate data for 31 reaches on abovetidal streams in the Council service area near Houston, Texas. Stream-habitat, land-use and population, and benthic aquatic insect metrics were determined for the 31 reaches. Statistical analyses were used to determine the stream-habitat, land-use and population, and aquatic insect variables that are strongly intercorrelated and that explain the greatest amount of variation between the reaches.

Comparison of stream-habitat and biological integrity scores computed for each of the 31 reaches indicated (1) reaches generally had larger stream-habitat integrity scores in drainage areas that were heavily forested and had fewer people per square mile, (2) larger biological integrity scores were significantly correlated with larger stream-habitat integrity scores, and (3) urban reaches generally had more simplified streamhabitat conditions and smaller biological integrity scores.

Seven reaches in the study area were selected as reference reaches on the basis of high streamhabitat integrity and high biological integrity. The reference-reaches median biological integrity score was equaled or exceeded by three reaches (one on Spring Creek and two on Cypress Creek) that are on the State of Texas 303(d) list of threatened or impaired waters with respect to aquatic life. This indicates that direct measures of biological integrity could be used to supplement surrogate- based designations of biological integrity such as the State list.

A statistically significant multipleregression model was developed that uses independent variables that can be obtained without fieldintensive studies to predict the biological integrity score for a reach. The deviation from the model's predicted score with the score based on biological sampling can be used to interpret the degree of biological impairment in a reach. Data from reaches outside the group of reaches used in this study are needed to test the validity of the multipleregression model.

\section{INTRODUCTION}

The Houston-Galveston Area Council (H-GAC) is the lead agency for the Texas Natural Resource Conservation Commission (TNRCC) Texas Clean Rivers Program (CRP) for watersheds near Houston, Texas. Under this program, H-GAC was required to develop (1996) and implement (1997-98) a regional water-quality monitoring program. The objective of the monitoring program is to provide the data needed to assess current water-quality conditions in the CRP river basins within the H-GAC service area. The assessment will be used to direct future regulatory and management actions on stream segments affected by point or nonpoint sources of contaminants. The CRP Technical Steering Committee for $\mathrm{H}-\mathrm{GAC}$ determined that additional monitoring activities should emphasize stream bioassessment methods to evaluate water quality in CRP river basins. $\mathrm{H}-\mathrm{GAC}$ elected to focus on biological assessment through synoptic sampling as the major component of its 1997-98 CRP monitoring program. 
The Texas Clean Rivers Act of 1991 (Texas Statute 818) (Texas Natural Resource Conservation Commission, 2000) requires the establishment of waterquality standards and the assessment and management of water quality. The Act requires the TNRCC to (1) assess water quality in the State; (2) investigate the effects of nonpoint-source pollution, toxic materials, and nutrient loadings; and (3) address discharge permit concerns. As a component of the CRP for the 1995-96 biennium, the TNRCC solicited proposals for "pilot projects" to address nonpoint-source pollution concerns relating to urban, agricultural, coastal, or geographic specific environments.

In response to this initiative, the U.S. Geological Survey (USGS), in cooperation with the H-GAC, conducted a study in 1997-98 to determine the status of in-stream biological resources, including fish and macrobenthic community structure and stream-habitat conditions. The objectives of this study were to (1) conduct an assessment of in-stream biological and habitat resources at above-tidal stream sites within the H-GAC service area; (2) establish reference-condition sites for comparison to non-reference sites; and (3) develop a multivariate predictive model for statistical comparisons of sites to determine levels of disturbance of in-stream biological resources. The first objective has been completed and documented by Moring and others (1998).

Objectives two and three, the focus of this report, were accomplished by (1) determining the streamhabitat, land-use, and (or) biological factors that account for the greatest variation between sites in the study area; (2) using the selected factors to compute a stream-habitat and biological integrity score for each site; (3) selecting a network of least-affected reference sites to establish a watershed-scale reference condition and, using the integrity scores, compare non-reference sites with reference sites; and (4) developing a multipleregression model to predict the status of the biological resources at sites without extensive biological sampling. Benthic macroinvertebrate data were used to compute a biological integrity score because benthic macroinvertebrates should provide better site-specific information about a site or reach than fish community data (Cuffney and others, 1993). Fish mobility tends to make determination of accurate species composition and relative abundance information more difficult. This is particularly true for a synoptic sampling study such as this one, designed with only one visit per site.

\section{Purpose and Scope}

This report evaluates the influence of stream habitat and land use on benthic macroinvertebrate indicators of biological integrity. Specifically, the report documents (1) the relation between stream habitat and land use, (2) the relation between benthic aquatic insects and land use, (3) the selection of reference reaches, (4) stream-habitat and biological integrity scores for reference and non-reference reaches, and (5) a multiple-regression model to predict biological integrity scores for reaches without biological sampling.

The evaluation is based on data collected during 1997-98 for 31 above-tidal reaches of streams in the Houston-Galveston area. The data collected consist of channel and riparian characteristics of the stream habitat, land-use and human population information, and distribution and composition of the benthic macroinvertebrate communities.

\section{Description of Study Area}

The H-GAC service area (fig. 1) consists of the 15-county Gulf Coast Planning Region that covers about 20,100 square kilometers $\left(\mathrm{km}^{2}\right)$ and has a population of about 4.3 million people. $\mathrm{H}-\mathrm{GAC}$ is a regionwide voluntary association of about 150 local governments and agencies that include 15 county governments, 106 cities, 19 school districts, and 10 soil and water conservation districts.

The watersheds assigned to $\mathrm{H}-\mathrm{GAC}$ under the CRP include the San Jacinto River Basin, TrinitySan Jacinto Coastal Basin, San Jacinto-Brazos Coastal Basin, and Brazos-Colorado Coastal Basin (fig. 1). The majority of the study area, including all coastal areas, is within the Western Gulf Coastal Plain ecoregion (Omernick, 1987). The Central Plains ecoregion extends into the northeastern part of the area, and the East Central, South Central, and Blackland Prairie ecoregions constitute the extreme northwestern part of the area. Natural features in the area include evergreen forests in the San Jacinto River Basin; extensively forested wetland corridors along the Trinity, Brazos, and Colorado Rivers, coastal bays, and estuaries; and non-forested wetlands in the large river floodplains and coastal areas. Cropland and pasture are the dominant rural land uses in the study area. Mixed urban, commercial, and industrial, particularly petrochemical industry along many of the waterways, are the dominant 


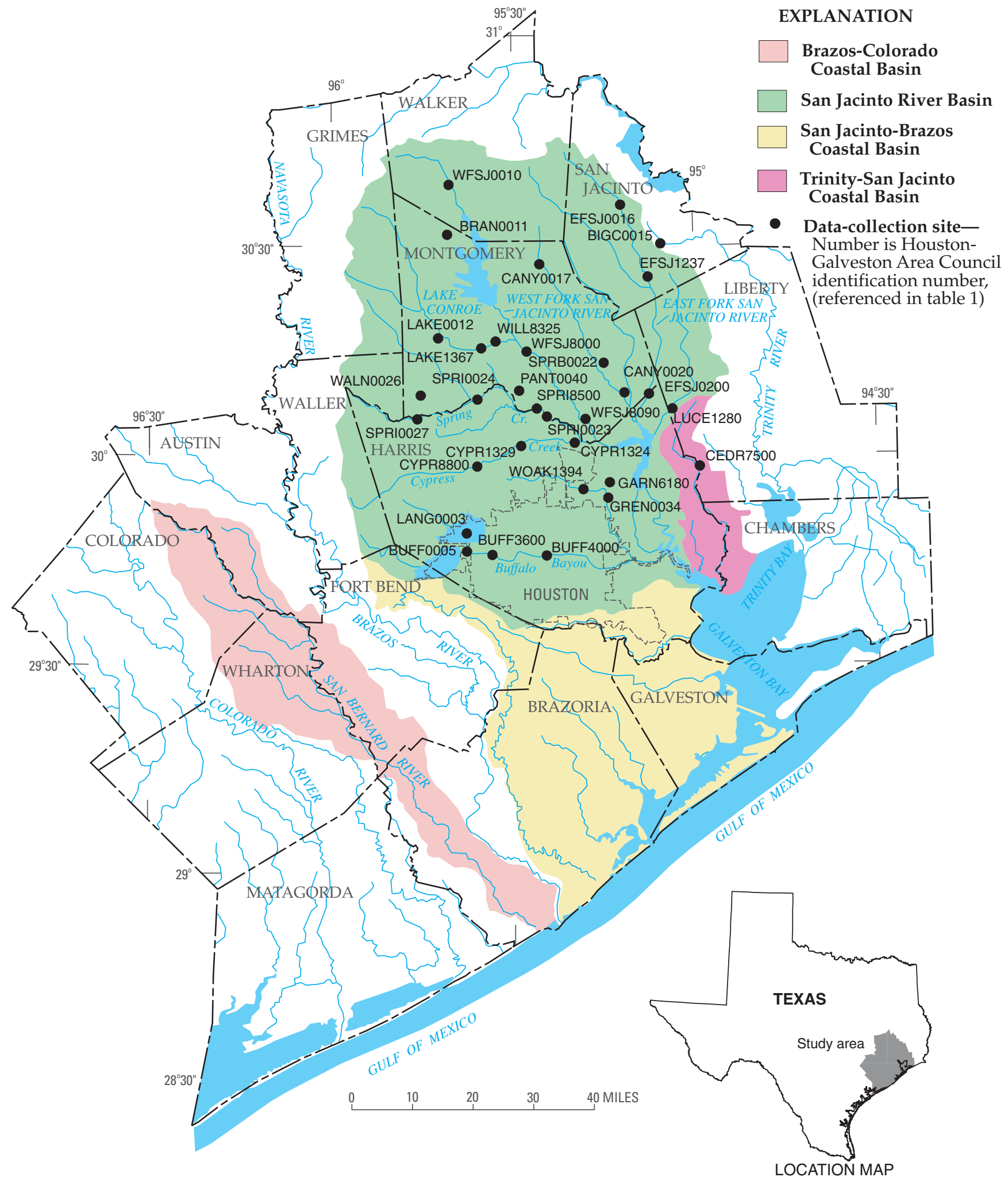

Figure 1. Data-collection sites in the Houston-Galveston Area Council service area. 
land uses in and around the greater Houston metropolitan area.

\section{APPROACH}

The selection of watershed-scale reference sites or a watershed-scale reference condition can provide a more direct and meaningful "point-of-reference" than a regional or state-wide criterion if the objective is to determine the status of one or more non-reference sites in a watershed. A recent development in water-quality monitoring is the use of a reference condition based on pre-established criteria for a wide range of sites rather than relying on a single reference or control site (Reynoldson and others, 1997). The reference condition is better defined as the best available or best attainable condition and is represented by information from a number of sites. The reference condition approach is useful in watersheds that are characterized by different types and intensities of land use and dominated by nonpoint-source conditions where the most reasonable or best attainable condition is something less than an ideal, non-affected condition. The overall approach in this study is to establish a reference condition through the selection of a group of reference sites (reaches) to determine the biological integrity of above-tidal, low-order streams in the San Jacinto River Basin. Below-tidal stream reaches were not included in this study because of the distinct differences between freshwater and tidal biological communities. In addition, much of the interpretation in this report assumes influences of the upstream drainage and does not consider the influence of fluctuations in salinity that occurs in tidal streams.

A reach-based compositing approach (Gurtz, 1994) rather than an equal-effort time-based approach (Barbour and others, 1997) was chosen as the method of sampling. The reach-based approach incorporates a stream-habitat component in the selection of a sampling location. The establishment of a well marked and monumented reach can allow for more easily repeated within-reach sampling at a location to assess trends or changes over time.

\section{Reach Selection}

H-GAC service-area base maps and geographic information system (GIS) coverages were acquired that include: (1) ecoregion and/or physiographic provinces; (2) watershed and subwatershed boundaries; (3) potential vegetation; (4) land use; (5) TNRCCdesignated stream segments and land-use classifica- tions; and (6) network of current water-quality monitoring stations. These map resources and appropriate databases were used to support the selection of potential sites and to assist in the screening of these potential sites to produce a final group of study sites.

For this study, a "site" is a sampling reach that is defined by the types and frequencies of geomorphic channel units or as a multiple of wetted channel width (Meador and others, 1993; Moring and others, 1998). The majority of sampling reaches are one full meander of channel length with a riffle-run-riffle-run or rifflepool-riffle-pool sequence of geomorphic channel units. If the reach lacked distinct multiple geomorphic channel units, the reach length was determined as a multiple of the wetted channel width. More detail on the selection and establishment of a sampling reach and information on project objectives and approach can be found in the report providing all project data (Moring and others, 1998) or by accessing the project web page at URL http://tx.usgs.gov/hgac/index.html

Thirty-nine reaches were initially selected for physical habitat and benthic macroinvertebrate assessments. Large river reaches on the Colorado, Brazos, Navasota, and San Bernard Rivers were not included in this study because the drainage areas for these reaches extend beyond the $\mathrm{H}-\mathrm{GAC}$ service area and were thought to be less influenced by adjacent land uses, upstream drainage area, and bank features than streams with smaller drainage areas. Reaches that were thought to be tidally influenced and the few sites in the Blackland Prairie ecoregion also were not included in this study. Because the number of smaller stream reaches outside the San Jacinto River Basin was not sufficient to provide adequate sample sizes for meaningful statistical analysis, the final selection included 30 reaches in the San Jacinto River Basin and 1 in the Trinity River Basin (fig. 1, table 1). The reach in the Trinity River Basin, Big Creek in the Big Creek Scenic Area, was included because its drainage area is heavily forested and largely undeveloped, and it is in the same physiographic setting as adjacent reaches in the San Jacinto River Basin.

\section{Assessment Components}

\section{Sampling-Reach Stream Habitat}

A field assessment of channel and riparian characteristics associated with each sampling reach was done to determine the geomorphic factors that most influence the benthic macroinvertebrate community 
Table 1. Data-collection sites for stream-habitat and benthic macroinvertebrate sampling in the HoustonGalveston Area Council service area

[H-GAC, Houston-Galveston Area Council; FM, farm road]

\begin{tabular}{|c|c|c|c|}
\hline \multirow{2}{*}{$\begin{array}{c}\text { Site } \\
\text { (reach name) }\end{array}$} & \multirow{2}{*}{$\begin{array}{c}\text { H-GAC } \\
\text { identification no. } \\
\text { (fig. 1) }\end{array}$} & \multicolumn{2}{|c|}{$\begin{array}{l}\text { Downstream reach } \\
\text { boundary coordinates }\end{array}$} \\
\hline & & Latitude & Longitude \\
\hline Big Creek in Big Creek Scenic Area/Sam Houston National Forest & BIGC0015 & $30^{\circ} 30^{\prime} 13^{\prime \prime}$ & $95^{\circ} 05^{\prime} 21^{\prime \prime}$ \\
\hline Branch Creek at FM 1375 bridge & BRAN0011 & $30^{\circ} 31^{\prime} 38^{\prime \prime}$ & $95^{\circ} 40^{\prime} 45^{\prime \prime}$ \\
\hline Buffalo Bayou at Eldridge Pkwy. & BUFF0005 & $29^{\circ} 46^{\prime} 13^{\prime \prime}$ & $95^{\circ} 37^{\prime} 15^{\prime \prime}$ \\
\hline Buffalo Bayou at West Belt Dr. & BUFF3600 & $29^{\circ} 45^{\prime} 43^{\prime \prime}$ & $95^{\circ} 33^{\prime} 27^{\prime \prime}$ \\
\hline Buffalo Bayou at Houston & BUFF4000 & $29^{\circ} 45^{\prime} 36^{\prime \prime}$ & $95^{\circ} 24^{\prime} 30^{\prime \prime}$ \\
\hline Caney Creek near Willis & CANY0017 & $30^{\circ} 27^{\prime} 21^{\prime \prime}$ & $95^{\circ} 25^{\prime} 28^{\prime \prime}$ \\
\hline Caney Creek near New Caney & CANY0020 & $30^{\circ} 08^{\prime} 55^{\prime \prime}$ & $95^{\circ} 11^{\prime} 30^{\prime \prime}$ \\
\hline Cedar Bayou near Crosby & CEDR7500 & $28^{\circ} 58^{\prime} 20^{\prime \prime}$ & $94^{\circ} 59^{\prime} 10^{\prime \prime}$ \\
\hline Cypress Creek west of I-45 and north of FM 1960 at Cypresswood & CYPR1324 & $30^{\circ} 01^{\prime} 45^{\prime \prime}$ & $95^{\circ} 19^{\prime} 47^{\prime \prime}$ \\
\hline Cypress Creek at Kuykendahl Rd. bridge & CYPR1329 & $30^{\circ} 01^{\prime} 19^{\prime \prime}$ & $95^{\circ} 28^{\prime} 38^{\prime \prime}$ \\
\hline Cypress Creek at Grant Rd. & CYPR8800 & $29^{\circ} 58^{\prime} 24^{\prime \prime}$ & $95^{\circ} 35^{\prime} 54^{\prime \prime}$ \\
\hline East Fork San Jacinto River at FM 945 & EFSJ0016 & $30^{\circ} 35^{\prime} 48^{\prime \prime}$ & $95^{\circ} 11^{\prime} 58^{\prime \prime}$ \\
\hline East Fork San Jacinto River near New Caney & EFSJ0200 & $30^{\circ} 08^{\prime} 43^{\prime \prime}$ & $95^{\circ} 07^{\prime} 27^{\prime \prime}$ \\
\hline East Fork San Jacinto River on FM 2025 & EFSJ1237 & $30^{\circ} 25^{\prime} 29^{\prime \prime}$ & $95^{\circ} 07^{\prime} 30^{\prime \prime}$ \\
\hline Greens Bayou at Mt. Houston Pkwy. & GREN0034 & $29^{\circ} 53^{\prime} 50^{\prime \prime}$ & $95^{\circ} 14^{\prime} 19^{\prime \prime}$ \\
\hline Lake Creek at FM 149 & LAKE0012 & $30^{\circ} 16^{\prime} 48^{\prime \prime}$ & $95^{\circ} 42^{\prime} 18^{\prime \prime}$ \\
\hline Lake Creek near Egypt & LAKE1367 & $30^{\circ} 15^{\prime} 21^{\prime \prime}$ & $95^{\circ} 34^{\prime} 70^{\prime \prime}$ \\
\hline Langham Creek at Patterson Rd. & LANG0003 & $29^{\circ} 48^{\prime} 49^{\prime \prime}$ & $95^{\circ} 37^{\prime} 40^{\prime \prime}$ \\
\hline Luce Bayou above Lake Houston near Huffman & LUCE1280 & $30^{\circ} 06^{\prime} 34^{\prime \prime}$ & $95^{\circ} 03^{\prime} 35^{\prime \prime}$ \\
\hline Panther Creek at The Woodlands & PANT0040 & $30^{\circ} 09^{\prime} 15^{\prime \prime}$ & $95^{\circ} 28^{\prime} 55^{\prime \prime}$ \\
\hline Spring Branch Creek at State 242/FM 2090 & SPRB0022 & $30^{\circ} 13^{\prime} 11^{\prime \prime}$ & $95^{\circ} 14^{\prime} 54^{\prime \prime}$ \\
\hline Spring Creek at Riley Fuzzel & SPRI0023 & $30^{\circ} 05^{\prime} 31^{\prime \prime}$ & $95^{\circ} 24^{\prime} 21^{\prime \prime}$ \\
\hline Spring Creek near Tomball & SPRI0024 & $30^{\circ} 08^{\prime} 00^{\prime \prime}$ & $95^{\circ} 35^{\prime} 50^{\prime \prime}$ \\
\hline Spring Creek on Robert Cemetery Rd. & SPRI0027 & $30^{\circ} 05^{\prime} 12^{\prime \prime}$ & $95^{\circ} 45^{\prime} 46^{\prime \prime}$ \\
\hline Spring Creek at Spring (I-45 bridge) & SPRI8500 & $30^{\circ} 06^{\prime} 41^{\prime \prime}$ & $95^{\circ} 26^{\prime} 01^{\prime \prime}$ \\
\hline Walnut Creek near Magnolia & WALN0026 & $30^{\circ} 08^{\prime} 36^{\prime \prime}$ & $95^{\circ} 45^{\prime} 12^{\prime \prime}$ \\
\hline West Fork San Jacinto River at State 30 & WFSJ0010 & $30^{\circ} 38^{\prime} 47^{\prime \prime}$ & $95^{\circ} 40^{\prime} 29^{\prime \prime}$ \\
\hline West Fork San Jacinto River near Conroe at I-45 & WFSJ8000 & $30^{\circ} 14^{\prime} 51^{\prime \prime}$ & $95^{\circ} 27^{\prime} 39^{\prime \prime}$ \\
\hline West Fork San Jacinto River above Lake Houston near Porter & WFSJ8090 & $30^{\circ} 05^{\prime} 09^{\prime \prime}$ & $95^{\circ} 17^{\prime} 59^{\prime \prime}$ \\
\hline Willow Creek near Tomball & WILL8325 & $30^{\circ} 16^{\prime} 19^{\prime \prime}$ & $95^{\circ} 32^{\prime} 47^{\prime \prime}$ \\
\hline White Oak Bayou at Bingle Rd. & WOAK1394 & $29^{\circ} 52^{\prime} 37^{\prime \prime}$ & $95^{\circ} 29^{\prime} 36^{\prime \prime}$ \\
\hline
\end{tabular}

within each reach (table 2). The riparian, channel, and environmental index (RCE) (Petersen, 1992) was calculated at each site to provide an initial and rapid assessment of the physical conditions of small to midsized channel reaches. The RCE consists of 16 scored metrics that include adjacent land use, continuity and vegetative makeup of the riparian and floodplain zones, channel structure, channel sediments, bank undercutting, aquatic vegetation, and type and frequency of geomorphic channel units. The RCE generates a unitless 
Table 2. Stream-habitat and land-use metrics determined for each stream reach

[m, meters; $\mathrm{m} / \mathrm{s}$, meters per second]

\begin{tabular}{|c|c|c|c|}
\hline In channel & Bank & Riparian zone & $\begin{array}{l}\text { Land use and } \\
\text { human population }\end{array}$ \\
\hline Linear reach length $(\mathrm{m})$ & Median right bank slope & $\begin{array}{l}\text { RCE (riparian, channel, and } \\
\text { environmental index) }\end{array}$ & Percent urban land use \\
\hline Curvilinear reach length $(\mathrm{m})$ & Median left bank slope & RCE maximum & Percent agricultural land use \\
\hline Sinuosity & Median bank slope & Canopy angle (degrees) & Percent forest land use \\
\hline Number of snags & Median right bank height (m) & & Percent wetland \\
\hline Number of stumps & Median left bank height (m) & & Percent barren land \\
\hline Number of undercut banks & Median bank height (m) & & Population density \\
\hline Number of other obstructions & Median bank height/width ratio & & \\
\hline Reach structural index & Median high-bank width (m) & & \\
\hline \multicolumn{4}{|l|}{ Number of bars } \\
\hline \multicolumn{4}{|l|}{ Median width (m) } \\
\hline \multicolumn{4}{|l|}{ Median depth (m) } \\
\hline \multicolumn{4}{|l|}{ Median velocity (m/s) } \\
\hline $\begin{array}{l}\text { Median wetted channel } \\
\text { width (m) }\end{array}$ & & & \\
\hline
\end{tabular}

numerical score that can be used to compare physical/biological conditions between different streams with the same level of site classification, such as small streams in an urban land-use setting or a particular physiographic setting. The numerical score is grouped into five classifications for use in stream-monitoring programs and for comparison to biological indices such as the index of biological integrity (IBI) for fish. The RCE was computed for the large river sites to provide useful site information, particularly channel metrics; however, the RCE bank and adjacent land-use metrics probably have little meaning for a large river channel that can be influenced more by inflows from the upstream drainage than by adjacent land uses. The variable, RCE maximum, was calculated as the RCE value for each reach divided by the maximum $\mathrm{RCE}$ for all reaches to standardize this variable.

In addition to the RCE, several reach-based and within-reach, transect-based metrics were made (table 2). Four channel cross sections extending from the right high-bank terrace to the left high-bank terrace were established in each reach corresponding to the four geomorphic channel units that were selected, or the cross sections were placed at regularly spaced intervals if the sampling reach length was based on a multiple of the median wetted channel width. The majority of the reaches were meandering channels in a low-gradient coastal plain, and the selection of geomorphic units generally corresponded to bends in the channel where riffles and/or pools are common and the runs are between the bends. Cuffney and others (1993) suggest six or more transects per reach, whereas Wang and others (1996) recommend a transect every two times the median wetted channel width. However, in this study, four cross sections in each reach were considered sufficient to characterize channel morphology and, thus, variability in stream velocity, depth, and substrate types and distribution. Longitudinal reach characteristics were normalized by dividing each frequency by the curvilinear reach length to allow for comparisons between 
reaches of different lengths. Stream-habitat metrics are defined in Moring and others (1998) and at the project web page at URL http://tx.usgs.gov/hgac/index.html

A Sokia Leitz Set 4A laser-operated total station was used to survey all transects and the entire reach to produce many of the reach habitat measures. All survey data were stored on-site in a datalogger that was electronically linked to the total station. The data were imported into an electronic spreadsheet and sorted and computations were made to determine linear reach length, curvilinear reach length, bank height, bank width, bank slope, wetted channel width, median depth, and frequencies of various in-channel structures such as woody debris and undercut banks. More details on the assessment of reach habitat features are available from Moring and others (1998).

\section{Land Use and Population}

Land-use and human population data were determined from above-reach polygons using ARC-INFO. The drainage area above each reach was delineated, and a polygon was established. Total acreage for the above-reach polygon was determined, and the percentage of land use within the polygon was determined for urban, agricultural, forest, wetland, and barren land use. Human population per square mile of the above-reach polygon was determined using data from the 1990 census (U.S. Census Bureau, 2000). These data and information were provided by GIS specialists with the H-GAC Community and Environmental Planning Division.

\section{Benthic Macroinvertebrate Sampling}

Three to five benthic macroinvertebrate samples collected in each reach from the richest targeted habitat (RTH) were composited and placed into a single container. The sample was wet-sieved in the field using a 425-micrometer $(\mu \mathrm{m})$ mesh 10-inch (in.)-diameter sieve, transferred to a sample jar, and fixed with 10 -percent buffered formalin. All samples were transferred from the 10-percent formalin to a 70-percent ethanol solution for preservation pending shipment to the laboratory for sample processing, identification, and enumeration. More details on field collection, processing, identification, and enumeration of the samples are presented in Moring and others (1998).

The method of collection was intentionally biased towards the collection of benthic aquatic insects (Cuffney and others, 1993) and not the collection of other macroinvertebrates. The RTH should have the greatest number of benthic macroinvertebrate species, particularly aquatic insects, and generally consists of a coarse substratum such as a cobble bottom or entrained woody debris and leaves in a riffle or moderately flowing section of the reach. Each sample was collected with a modified surber sampler (Cuffney and others, 1993) consisting of a rectangular-framed sampler with a $425-\mu \mathrm{m}$ mesh net and attached $425-\mu \mathrm{m}$ plankton bucket.

The distribution and composition of benthic macroinvertebrate communities in streams respond to natural changes in the physical and chemical conditions that occur along the longitudinal axis of the river (Vannote and others, 1980). Changes in environmental variables such as riparian zone condition, water temperature, light penetration, streamflow regimes, and water and sediment chemistry all influence the type of benthic invertebrate community present at a given location. From upstream to downstream along a stream reach, changes in the variety of stream habitats (including riffles, runs, and pools) influence the type and stability of substrates and the stream depths and velocities. These changes in stream habitats and their characteristics affect the presence, absence, and relative abundance of benthic macroinvertebrate taxa.

Biological metrics computed from the benthic macroinvertebrate data included numbers and percentages of major trophic groups and major taxa, taxa richness, and several diversity and other selected indices (table 3).

\section{Data Analysis}

All reach data were keyed into an electronic spreadsheet, sorted, and reviewed for any errors. Data were electronically transferred from the spreadsheet to a statistical software package (STATISTICA, 1999) for data summary and analysis. Statistical analyses included a principal components analysis (PCA), a two-sample student's t-test, and a multiple regression. PCA is a type of community ordination procedure in which sampling units are arranged in relation to one or more coordinate axes in a way that their relative positions to the axes and to one another provide the maximum information about their ecological similarities (Ludwig and Reynolds, 1988). The PCA often is used to determine which biotic or abiotic variables explain the greatest variability between sites, populations of organisms, or individual organisms. Prior to using the data in any multivariate statistical analyses, 
Table 3. Benthic macroinvertebrate metrics determined for each stream reach

[EPT, Ephemeroptera-Plecoptera-Trichoptera]

\begin{tabular}{lll}
\hline \multicolumn{1}{c}{ Numbers of taxa } & \multicolumn{1}{c}{ Percentages } & \multicolumn{1}{c}{ Indices } \\
\hline Number of taxa & Percent EPT taxa & EPT taxa richness \\
Number of filterers & Percent Chironomidae & Shannon-Weiner diversity index \\
Number of gatherers & Percent Ephemeroptera & Hilsenhoff's biotic index \\
Number of predators & Percent Oligochaeta & Margelef's richness index \\
Number of scrapers & Percent Plecoptera & Pielou's evenness index \\
Number of shredders & Percent filterers & Simpson's heterogeneity index \\
& Percent gatherers & \\
& Percent predators & \\
\hline
\end{tabular}

all non-proportional stream-habitat variables were logtransformed as $\log 10(\mathrm{x}+1)$ and proportional land-use variables were arcsine transformed (arcsin of the square root of the proportion) to reduce the heteroscedasticity (or non-normality) of the data (Zar, 1984). All transformed variables were tested for normality using a Komolgorov-Smirnov single sample test. A correlation matrix was used as the input matrix to extract principal components followed by a varimax rotation procedure to maximize the variance of factor loadings on each of the principal components (STATISTICA, 1999). The two-sample student's t-test is a parametric statistical test to determine if two means are the same (Zar, 1984). A multiple regression is an expanded version of a simple linear regression in which the dependent variable $\left(\mathrm{Y}_{\mathrm{i}}\right)$ is influenced by multiple independent variables $\left(\mathrm{X}_{\mathrm{i} \ldots \mathrm{n}}\right)$. Multiple regression often is used in ecological investigations to predict a value for a dependent biotic variable using one or more abiotic independent variables.

\section{INFLUENCE OF STREAM HABITAT AND LAND USE ON BENTHIC MACROINVERTE- BRATE INDICATORS OF BIOLOGICAL INTEGRITY}

Stream-habitat and land-use variables that explain the greatest variation between the reaches were determined and used to select seven reference reaches. Stream-habitat and biological integrity scores were computed for each of the 31 reaches. A multipleregression model was developed to predict the biological integrity of a site using several, easily determined, variables. Because land use in the study area ranges from older urban in metropolitan Houston to rural forest in the national forests north of Houston, the stream-habitat and land-use variables selected were highly disparate.

\section{Relation Between Stream Habitat and Land Use}

A multivariate statistical procedure, PCA was used as a "variable reduction" technique to determine those stream-habitat and land-use variables that are strongly intercorrelated and those variables that explain the greatest variation between reaches. Variables with PCA factor loadings greater than or equal to 0.7 were considered for further analysis. The first PCA indicated that among the stream-habitat variables, reach structural index, RCE maximum, median bank height/width ratio, median high-bank width, median bank height, and median wetted channel width all had factor loadings greater than 0.7 on one or more of the first three principal components (table 4). The larger the factor loading for a given variable, the more among-reach variation that variable explains. The first three principal components accounted for 74.1 percent of the variation between reaches. Median bank height/width ratio, median high-bank width, median bank height, and median bank slope were all significantly intercorrelated. Because of problems encountered selecting highbank locations during the reach surveys, these four variables were not used in any additional analyses.

A second PCA was done on the land-use variables - urban, agricultural, rangeland, forest, wetland, and barren - and population density (number of people per square mile). The first three principal components accounted for 72.2 percent of the variation between reaches (table 5). Percent agricultural, forest, and urban land uses and population density in the 
Table 4. Factor loadings from principal components analysis (PCA) greater than 0.7 for stream-habitat variables and proportion of variation explained by each principal component

\begin{tabular}{lccc}
\hline \multicolumn{1}{c}{ Stream-habitat variable } & $\begin{array}{c}\text { First principal } \\
\text { component }\end{array}$ & $\begin{array}{c}\text { Second principal } \\
\text { component }\end{array}$ & $\begin{array}{c}\text { Third principal } \\
\text { component }\end{array}$ \\
\hline Reach structural index & -0.895 & & \\
RCE maximum & -.770 & 0.943 & \\
Median bank height/width ratio & & & -0.917 \\
Median high-bank width & & & -.785 \\
Median bank height & & .283 & -.741 \\
Median wetted channel width & .240 & & .218 \\
Proportion of variation explained & & & .741 \\
Proportion of total variation explained & & & \\
\hline
\end{tabular}

Table 5. Factor loadings from principal components analysis (PCA) greater than 0.7 for land-use and population variables and proportion of variation explained by each principal component

\begin{tabular}{lccc}
\hline \multicolumn{1}{c}{ Land-use and population variable } & $\begin{array}{c}\text { First principal } \\
\text { component }\end{array}$ & $\begin{array}{c}\text { Second principal } \\
\text { component }\end{array}$ & $\begin{array}{c}\text { Third principal } \\
\text { component }\end{array}$ \\
\hline Percent agricultural & 0.929 & & \\
Percent forest & -.914 & 0.869 & \\
Percent urban & & .846 & \\
Population density & & & -0.725 \\
Percent rangeland & & .258 & .719 \\
Percent wetland & .316 & & .148 \\
Proportion of variation explained & & & .722 \\
Proportion of total variation explained & & & \\
\hline
\end{tabular}

drainage area above each reach all had loadings greater than 0.7 on one of the first two principal components. Percent rangeland and wetland only slightly exceeded a 0.7 loading on the third principal component. Rangeland is generally a small part of the land use in the drainage area above each reach and often is difficult to separate from agricultural or other cultivation land uses. In the low-gradient coastal plains of the study area, the majority of wetlands in the drainage area above each reach are standing water bodies, such as oxbow lakes, that are separated from the fluvial stream corridors for much of the year. Therefore, percent rangeland and wetland were not included in subsequent data analyses.

Reaches were grouped by their dominant land use, and comparisons were made between the PCAselected stream-habitat and land-use variables (figs. 2 and 3). Urban and agricultural land uses were combined for each reach to compare anthropogenic with nonanthropogenic land-use categories. Median reach structural index was significantly larger for those above- reach drainage areas that were dominated by forest land use (median $=157.6, \mathrm{t}=-3.2, \mathrm{p}<0.05$ ). Median RCE maximum also was significantly larger for forest land use than for urban-agricultural land use (median $=78.3$, $\mathrm{t}=-3.51, \mathrm{p}<0.05)$. The larger medians for the drainage areas dominated by forest are an indication of the greater structural complexity in the channel, greater bank stability, and high integrity of the riparian zone. In general, the more forested the drainage area, the less disturbed the riparian zone, and the greater the source of structural material such as leaves, limbs, and tree logs that become habitat for aquatic organisms.

The number of people per square mile in the drainage area above each reach was significantly negatively correlated (fig. 3 ) with reach structural index $(\mathrm{r}=-0.37, \mathrm{p}<0.05)$ and RCE maximum $(\mathrm{r}=-0.63$, $\mathrm{p}<0.05)$. Reaches in drainage areas with more people per square mile tend to lack in-channel structural complexity, have less stable banks, be more channelized, and lack channel meandering. Reaches on White Oak 

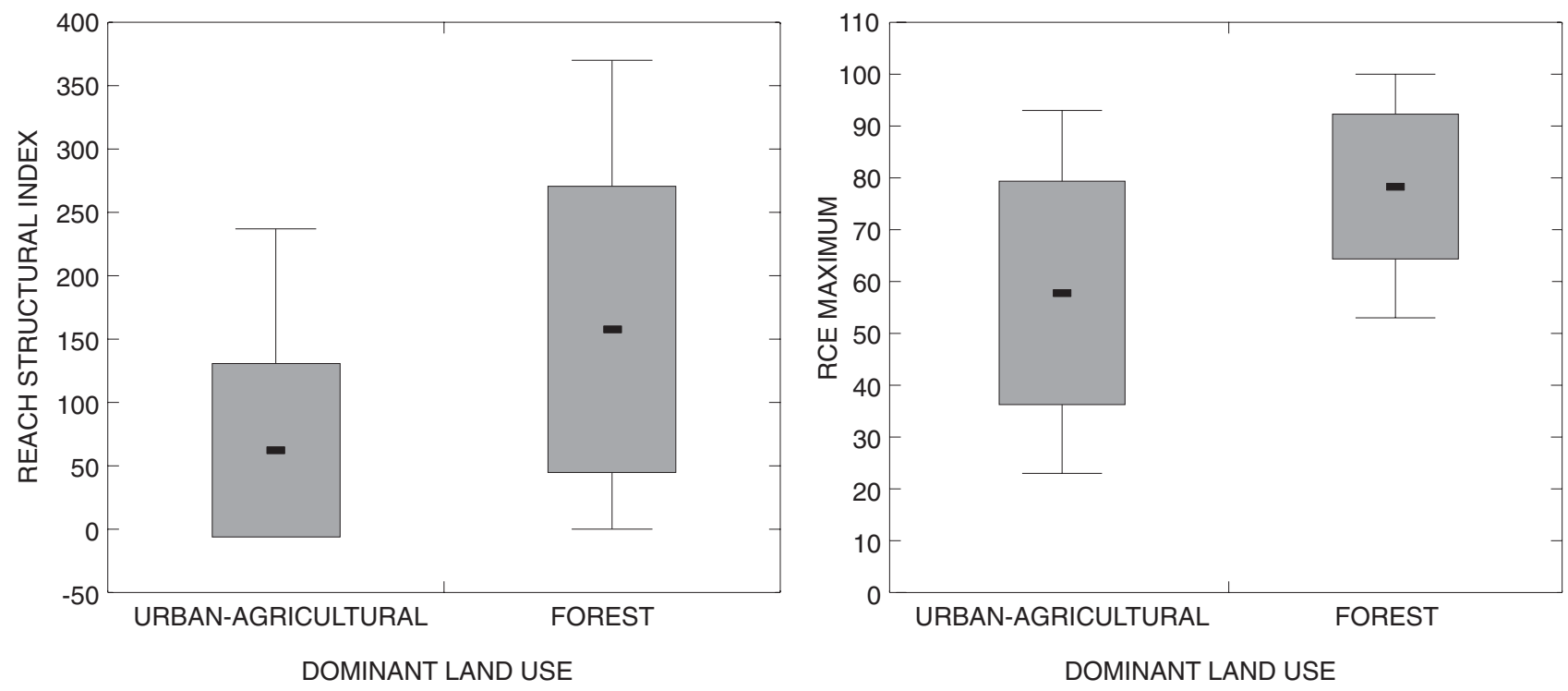

EXPLANATION

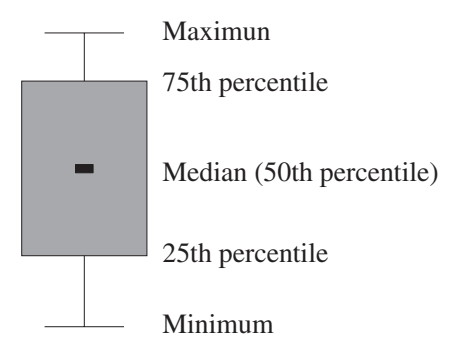

Figure 2. Distribution of selected stream-habitat variables for reaches grouped by dominant land use.

Bayou (WOAK1394) and Greens Bayou (GREN0034) at Houston are typical of these types of reaches.

\section{Relation Between Benthic Aquatic Insects and Land Use}

Non-insect benthic macroinvertebrates are not included in any analyses or discussions in this section of the report.

A PCA was done using the transformed benthic aquatic insect variables to select those variables that explain the greatest variation between the 31 reaches and to determine which variables are most intercorrelated. These variables - percent EphemeropteraPlecoptera-Trichoptera (EPT) taxa, percent filterers, Hilsenhoff's biotic index, number of taxa, ShannonWiener diversity index, Margalef's richness index, Simpson's heterogeneity index, percent shredders, and percent Oligochaeta — all had factor loadings greater than 0.7 on at least one of the first four principal components (table 6). The first four principal components accounted for 82.2 percent of the variation between reaches. Because the proportional variables, Ephemeroptera, Plecoptera, and Trichoptera, were all highly positively intercorrelated, percent EPT taxa (sum of these three proportional variables) was used in the PCA. Percent filterers and percent shredders were not used for further analysis because these variables are trophic classifications comprised of many of the same taxa that make up the variable, percent EPT. Therefore, use of these variables and EPT would be somewhat redundant. Percent Chironomidae did not have a loading greater than 0.7 after PCA analysis. However, because Chironomidae was the dominant group at many sites, both in number of taxa and in number of individuals, this variable was selected for further analysis. The Shannon-Wiener diversity and Margalef's richness indices were not used in additional analyses because of sample-size bias and other concerns (Ludwig and Reynolds, 1988). Percent EPT taxa, Hilsenhoff's biotic 


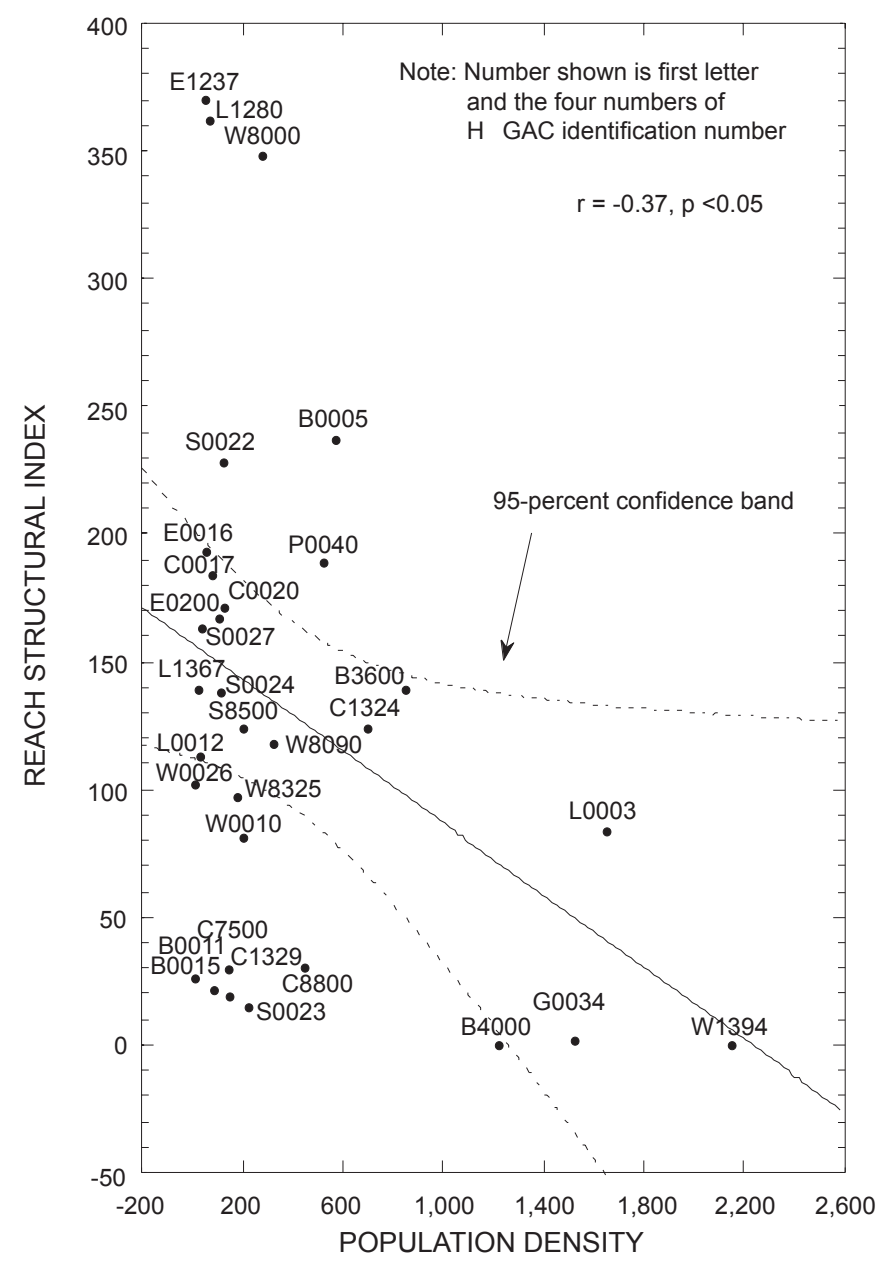

(NUMBER OF PEOPLE PER SQUARE MILE)

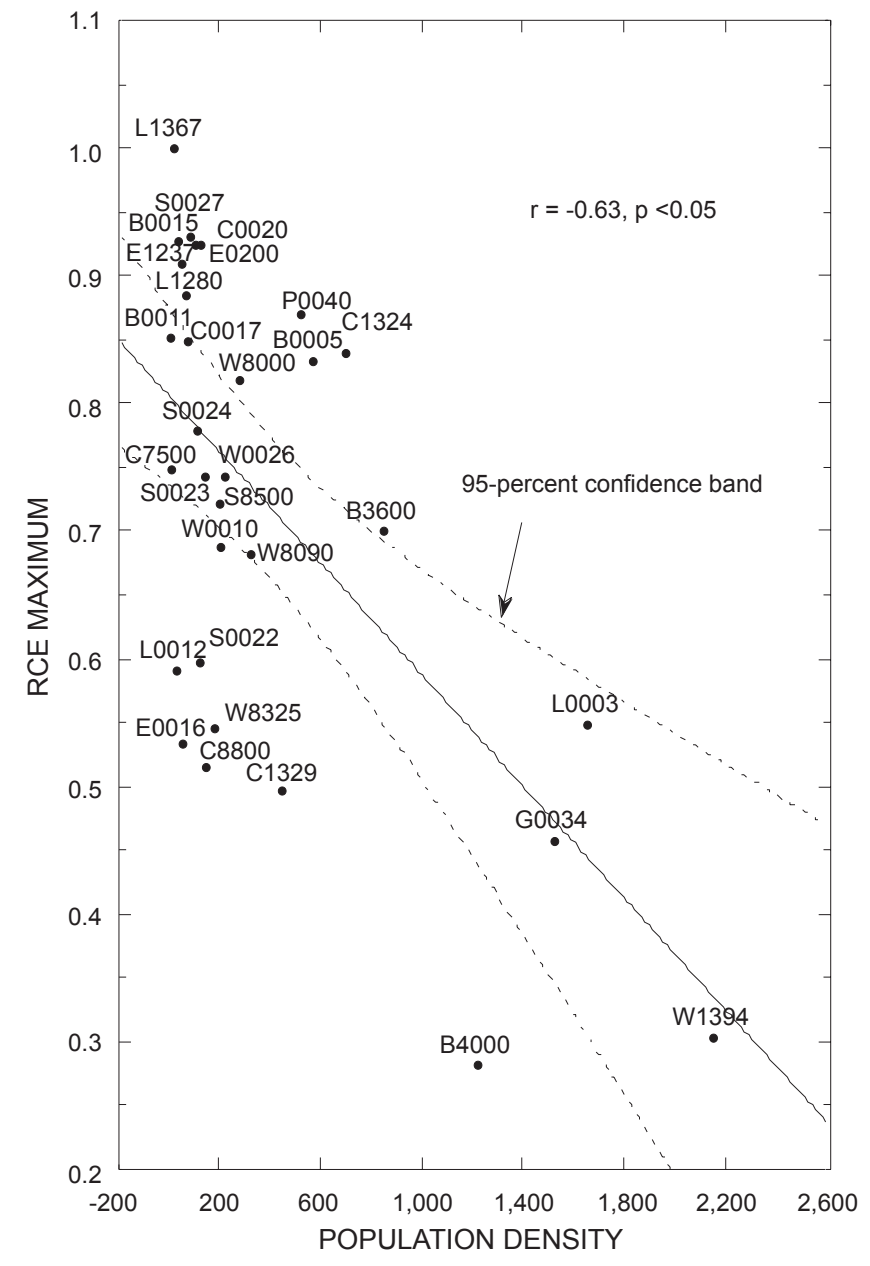

(NUMBER OF PEOPLE PER SQUARE MILE)

Figure 3. Relation between population density in above-reach drainage areas and selected stream-habitat variables.

Table 6. Factor loadings from principal components analysis (PCA) greater than 0.7 for benthic aquatic insect variables and proportion of variation explained by each principal component

[EPT, Ephemeroptera-Plecoptera-Trichoptera]

\begin{tabular}{lcccc}
\hline \multicolumn{1}{c}{ Benthic aquatic insect variable } & $\begin{array}{c}\text { First principal } \\
\text { component }\end{array}$ & $\begin{array}{c}\text { Second principal } \\
\text { component }\end{array}$ & $\begin{array}{c}\text { Third principal } \\
\text { component }\end{array}$ & $\begin{array}{c}\text { Fourth principal } \\
\text { component }\end{array}$ \\
\hline Percent EPT taxa & -0.904 & & & \\
Percent filterers & .722 & & & \\
Hilsenhoff's biotic index & .937 & & & \\
Number of taxa & & 0.874 & & \\
Shannon-Weiner diversity index & & .968 & & \\
Margelef's richness index & & .934 & 0.858 & -0.953 \\
Simpson's heterogeneity index & & .856 & & .140 \\
Percent shredders & & & .126 & .822 \\
Percent Oligochaeta & .263 & .293 & & \\
Proportion of variation explained & & & & \\
Proportion of total variation explained & & & & \\
\hline
\end{tabular}



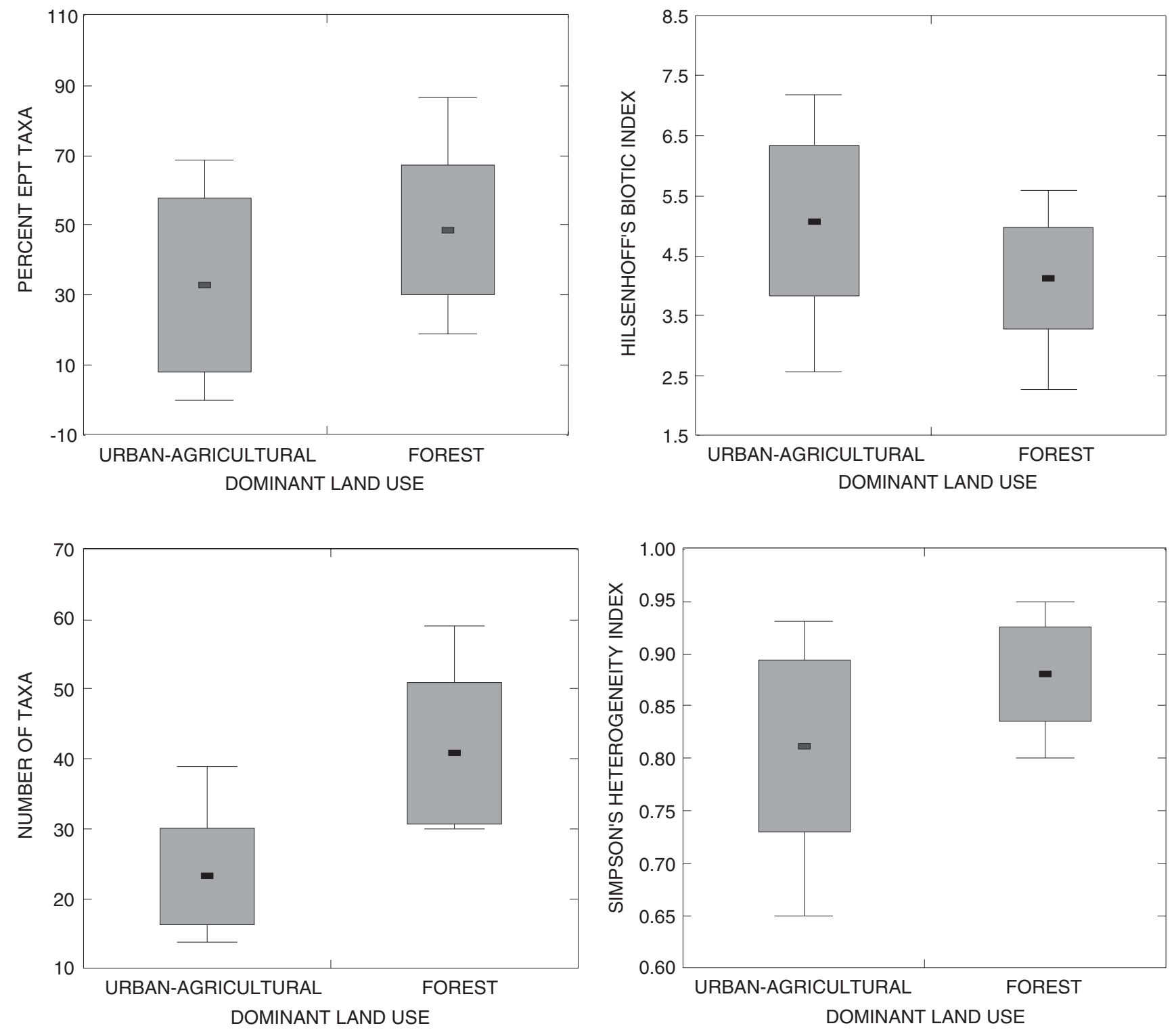

EXPLANATION

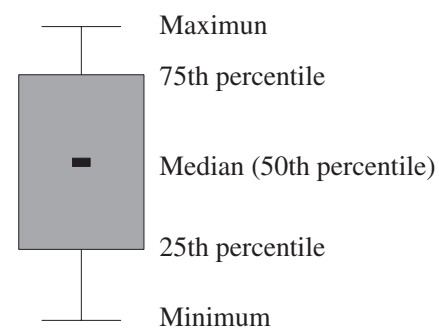

Figure 4. Distribution of selected benthic aquatic insect variables for reaches grouped by dominant land use.

index, number of taxa, Simpson's heterogeneity index, and percent Oligochaeta and Chironomidae were selected for further analysis.
The reaches grouped by dominant land use were compared for the six selected variables (fig. 4). Percent EPT taxa, number of taxa, and Simpson's heterogeneity 


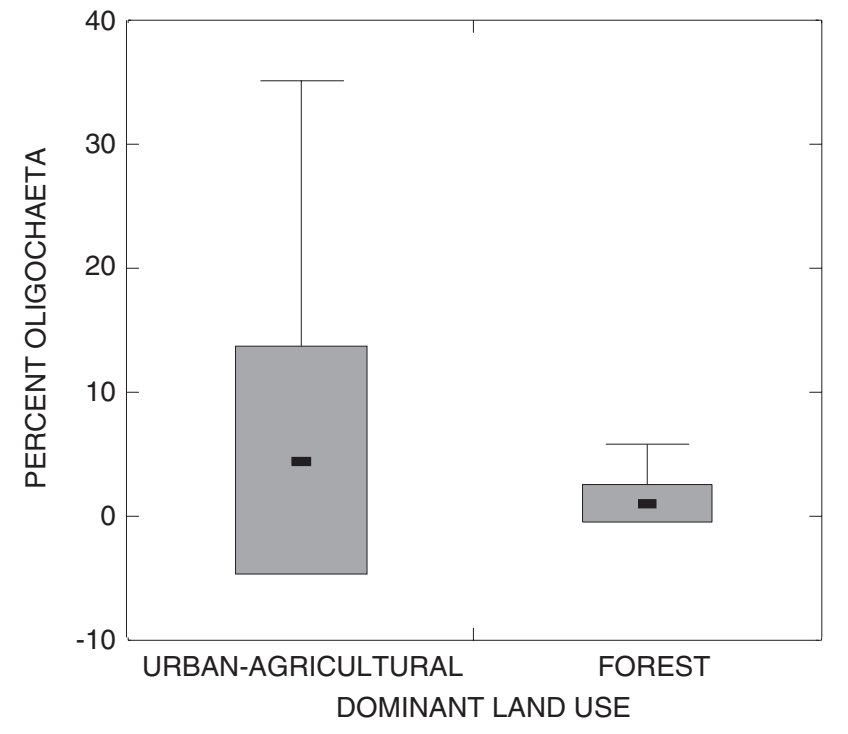

Figure 4.-Continued.

index all had smaller medians for drainage areas dominated by urban-agricultural land uses than for drainage areas dominated by forest land use. However, only number of taxa (median $=40.9, \mathrm{t}=-5.63, \mathrm{p}<0.05)$ and Simpson's index (median $=0.88, \mathrm{t}=-2.92, \mathrm{p}<0.05)$ had medians that were significantly larger for drainage areas dominated by forest land use. The medians for percent Oligochaeta and Chironomidae were larger in urbanagricultural drainage areas, but not significantly larger. The median Hilsenhoff's index was significantly larger for drainage areas dominated by urban-agricultural land use (median $=5.09, \mathrm{t}=2.48, \mathrm{p}<0.05)$. The Hilsenhoff's index is a community metric that incorporates characteristics of aquatic insect taxonomic diversity with tolerance characteristics; the larger the index, the more affected the community (Hilsenhoff, 1987).

The number of people per square mile was significantly negatively correlated with percent EPT taxa $(\mathrm{r}=-0.45, \mathrm{p}<0.05)$ and number of taxa $(\mathrm{r}=-0.56$, $\mathrm{p}<0.05$ ) (fig. 5). Greater percent EPT taxa and number of taxa were associated with those reaches and associated drainage areas that are well forested, have more stable riparian zones, and have more in-channel structures such as woody snags and undercut banks. The number of people per square mile in the drainage area above each reach was significantly positively correlated with percent Chironomidae $(r=0.58, \mathrm{p}<0.05)$. Larger percentages of chironomids are often associated with large river reaches, more lentic or "lake-like" conditions, or in water bodies that have small dissolved oxy-

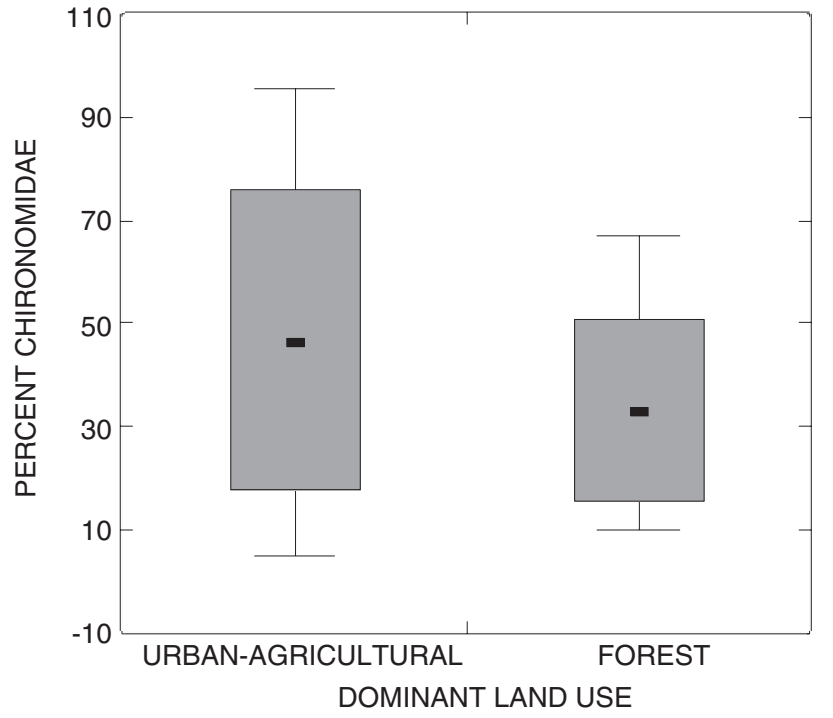

gen concentrations (Ward, 1992). Comparison of the number of people per square mile in the reach drainage area with Hilsenhoff's index, Simpson's index, and percent Oligochaeta showed no significant correlations.

\section{Selection of Reference Reaches}

The six variables that explained the greatest variability between reaches as determined by the PCA were used in the selection of reference reaches: two stream-habitat variables-reach structural index and RCE maximum - and four benthic aquatic insect variables-percent EPT taxa, number of taxa, Hilsenhoff's biotic index, and percent Chironomidae. In this report, a reference reach is defined as a reach that has high stream-habitat integrity as measured by the two streamhabitat variables selected or high biological integrity as measured by the status of the aquatic insect taxa.

Several screening criteria were used to develop a pool of potential reference reaches. Reaches with structural index or RCE maximum (fig. 6) or with percent EPT taxa or number of taxa (fig. 7) greater than or equal to the 90th percentile for these variables were selected as potential reference reaches. Reaches with percent Chironomidae or Hilsenhoff's index (fig. 8) less than or equal to the 10th percentile for this variable also were selected as potential reaches. Sixteen reaches met the criteria: BIGC0015, BRAN0011, BUFF0005, CANY0017, CANY0020, CYPR1324, CYPR8800, EFSJ0016, EFSJ0200, EFSJ1237, LAKE0012, 

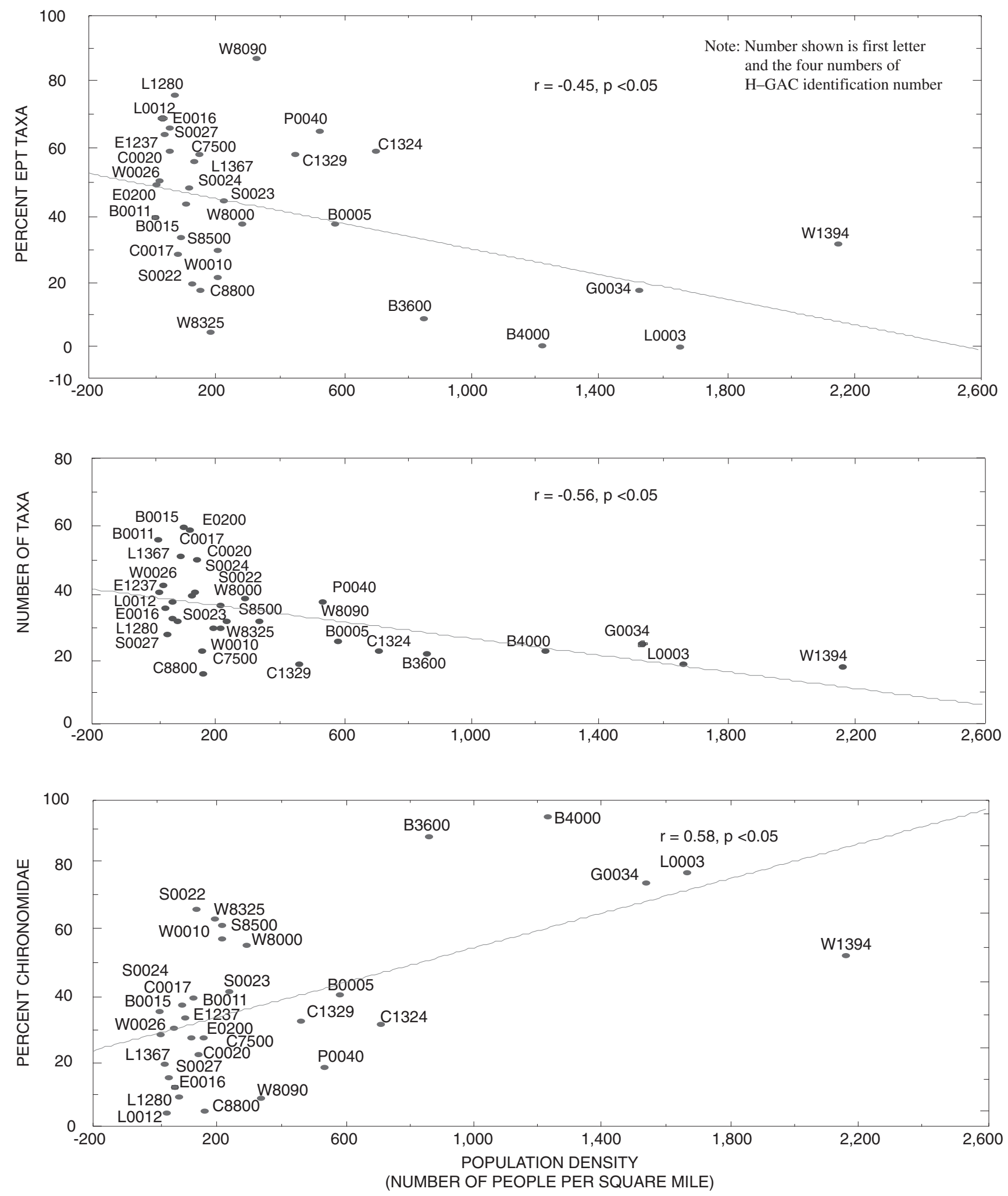

Figure 5. Relation between population density in above-reach drainage areas and selected benthic aquatic insect variables. 

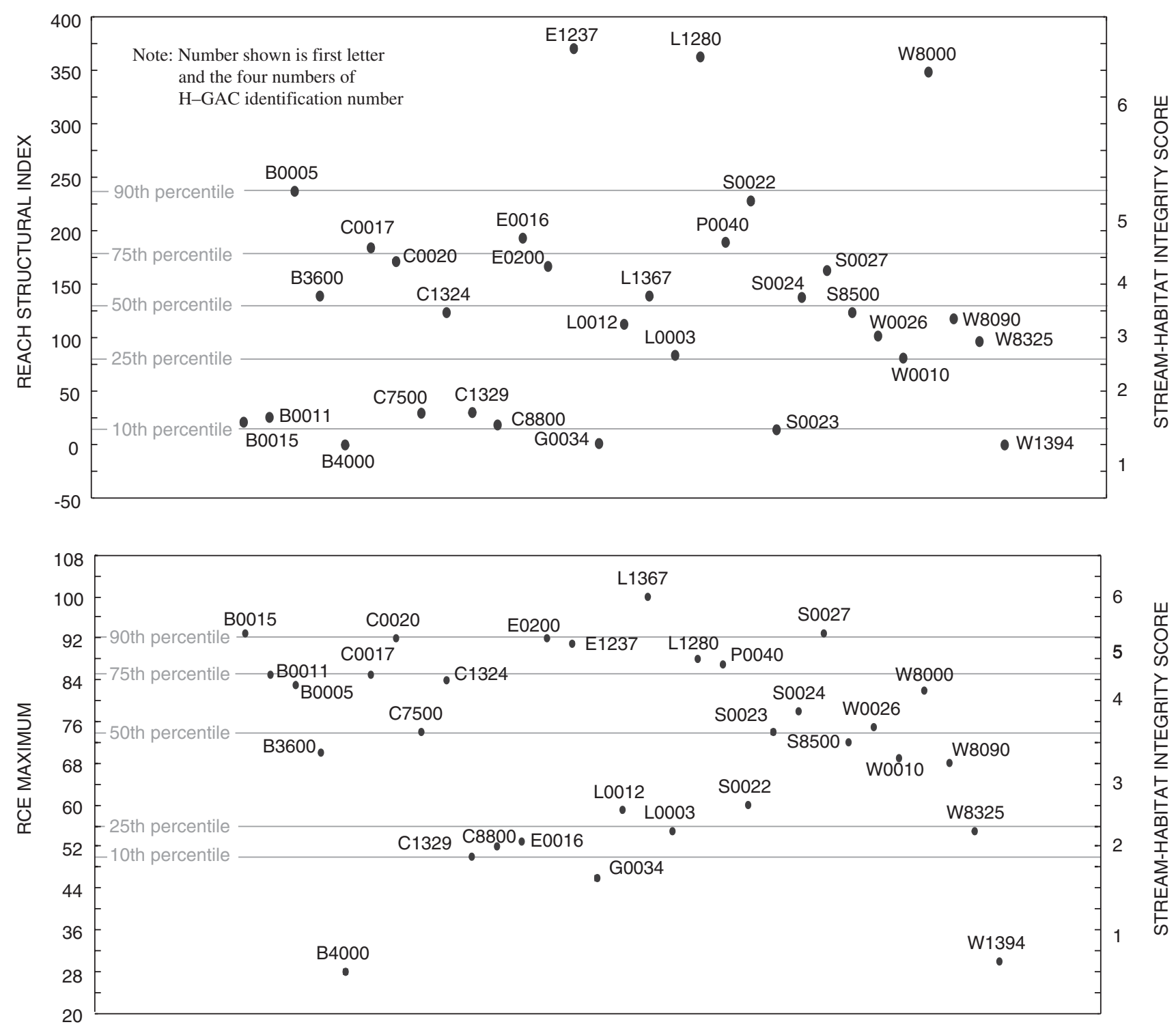

Figure 6. Reach structural index and RCE maximum for selected reaches classified by percentile and streamhabitat integrity score.

\section{LAKE1367, LUCE1280, SPRI0027, WFSJ8000, and WFSJ8090.}

The pool of reaches selected, after screening with the stream habitat and aquatic insect variables, were further screened using the percentage of drainage area above each reach that is forest land use and the number of wastewater outfalls in the drainage area. The greater Houston metropolitan area has a relatively large number of wastewater discharges partly because of the zoning statutes in the area (Todd Running, Houston-Galveston Area Council, personal commun., 1999). Those reaches with a drainage area that was greater than or equal to 80-percent forest land use and that had five or fewer wastewater outfalls were selected as reference reaches. This resulted in six reaches: BIGC0015, BRAN0011, EFSJ0016, EFSJ0200, EFSJ1237, and LUCE1280. The reach CANY0017 is 61-percent forest land use with five wastewater outfalls in its drainage area. Because of its location and number of taxa, CANY0017 was selected as the seventh reference reach.

\section{Stream-Habitat and Biological Integrity Scores}

Stream-habitat and biological integrity scores were computed for each of the 31 reaches. The 

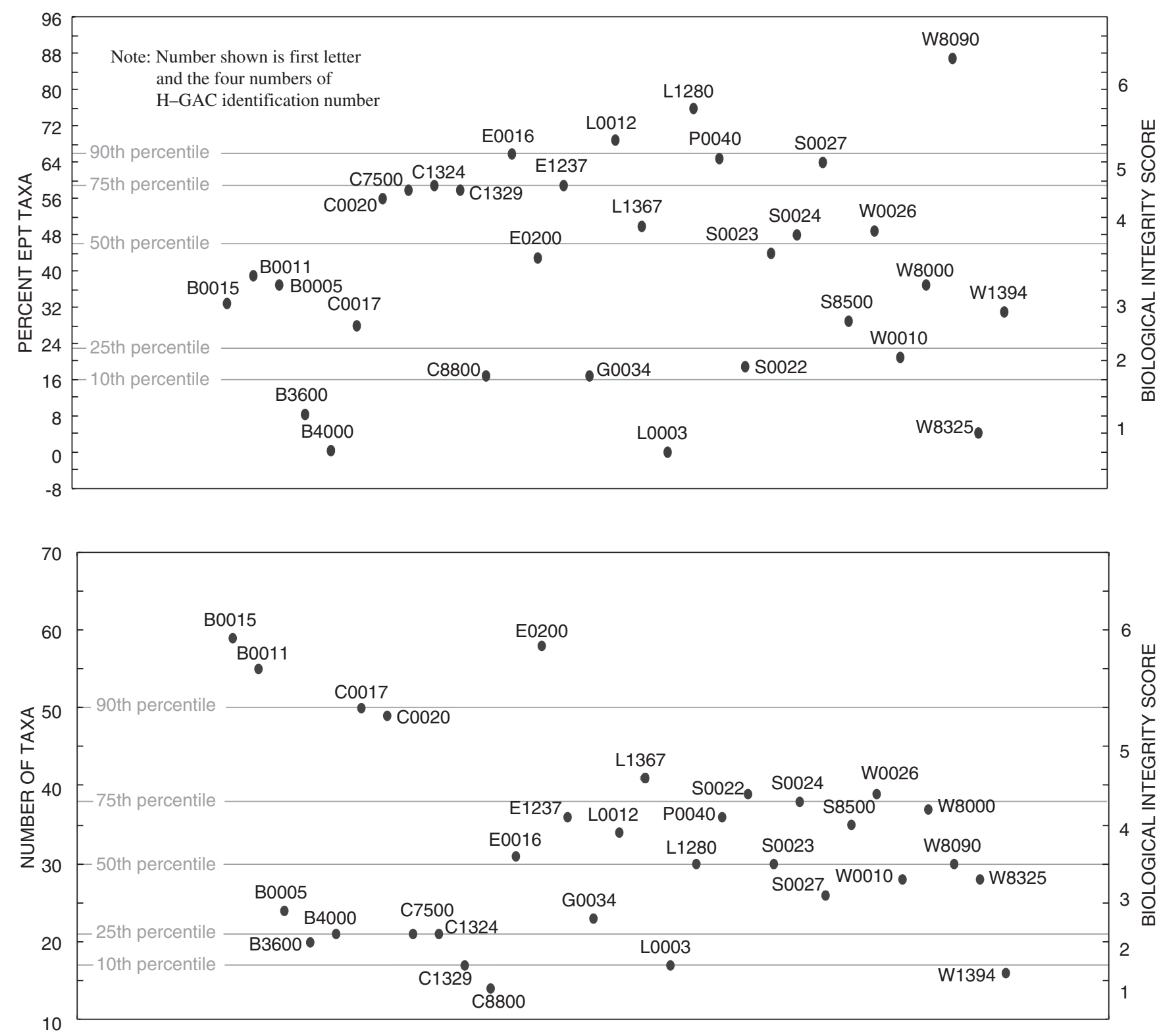

Figure 7. Percent EPT taxa and number of taxa for selected reaches classified by percentile and biological integrity score.

PCA-selected stream-habitat variables reach structural index and RCE maximum were used to compute the stream-habitat integrity score; the aquatic insect variables percent EPT taxa, number of taxa, Hilsenhoff's biotic index, and percent Chironomidae were used to compute the biological integrity score. Scores for each variable were assigned as follows: Scores of 6, 5, and 4 were assigned to the variables reach structural index, RCE maximum, percent EPT taxa, and number of taxa that were greater than or equal to the 90th, 75 th, or 50th percentiles, respectively (figs. 6 and 7). Scores of 3, 2, and 1 were assigned to those same variables that were between the 50th and 25th percentiles and less than or equal to the 25 th or 10 th percentiles, respectively (figs. 6 and 7). Thus, the greater the percentile, the higher the integrity score for these variables. The scoring was reversed for the variables Hilsenhoff's biotic index and percent Chironomidae, with greater percentiles assigned lower integrity scores (fig. 8).

The integrity scores for the two stream-habitat and four biological variables were summed separately (table 7). East Fork San Jacinto River on FM 2025 

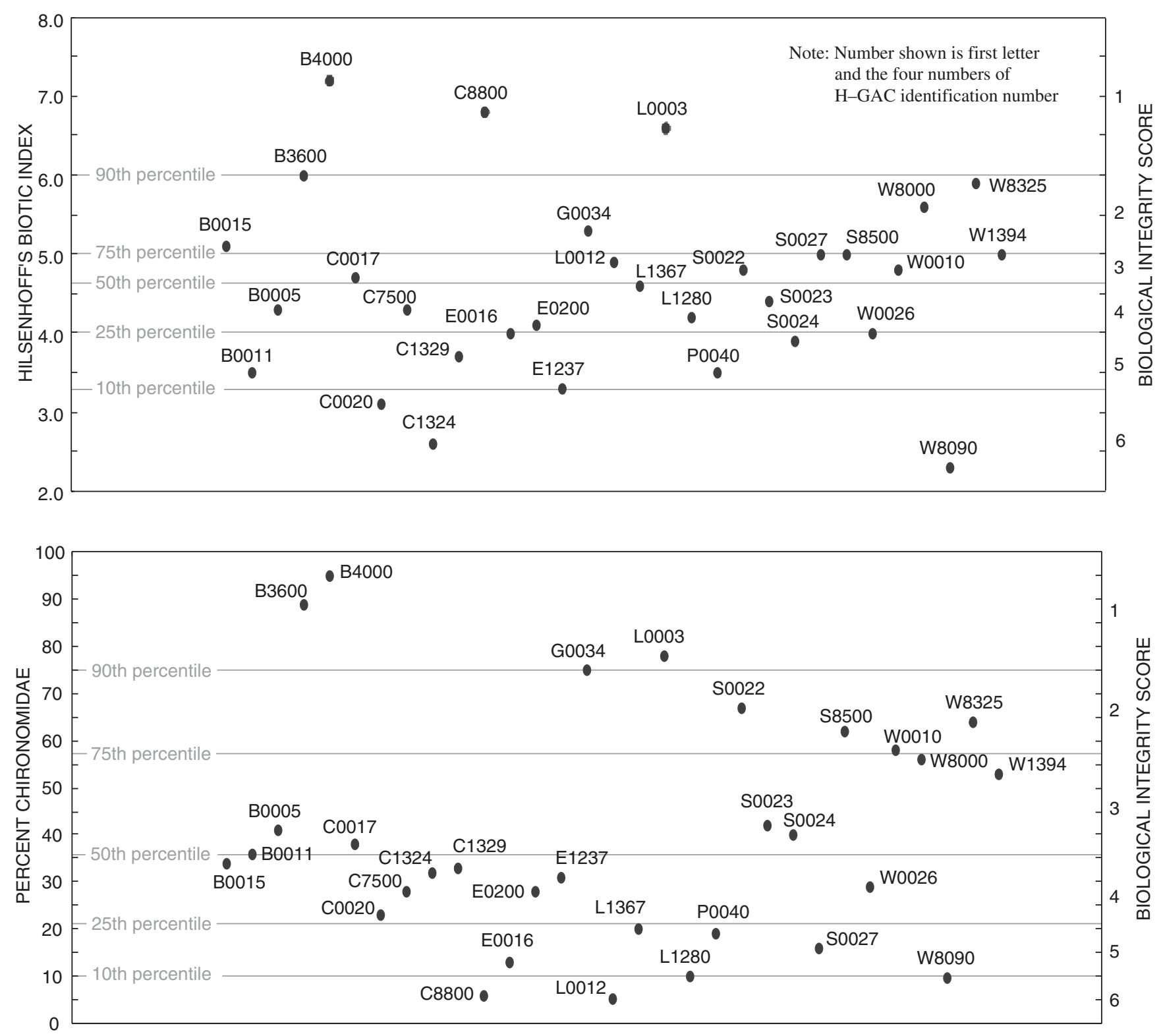

Figure 8. Hilsenhoff's biotic index and percent Chironomidae for selected reaches classified by percentile and biological integrity score.

(EFSJ1237) and Luce Bayou above Lake Houston near Huffman (LUCE1280) each had the largest streamhabitat integrity score of 11 , and White Oak Bayou at Bingle Road (WOAK1394) had the smallest score of 1. West Fork San Jacinto River above Lake Houston near Porter (WFSJ8090) had the largest biological integrity score of 22, and Buffalo Bayou at West Belt Drive (BUFF3600), Buffalo Bayou at Houston (BUFF4000), and Langham Creek at Patterson Road (LANG0003) each had the smallest score of 5. The stream-habitat and biological integrity scores (fig. 9) were significantly positively correlated $(\mathrm{r}=0.58, \mathrm{p}=0.0006)$.

Median stream-habitat and biological integrity scores were computed for the seven reference reaches for comparison with all selected reaches (fig. 10). The median stream-habitat integrity score for the reference reaches is 10 . All reaches with stream-habitat integrity scores greater than the reference-reaches median have relatively well-forested, non-urbanized drainage areas. Smaller stream-habitat integrity scores 
Table 7. Stream-habitat and biological integrity scores for selected reaches

[H-GAC, Houston-Galveston Area Council; --, not applicable; FM, farm road]

\begin{tabular}{|c|c|c|c|c|}
\hline \multirow[b]{2}{*}{ Site (reach name) } & \multirow{2}{*}{$\begin{array}{c}\text { H-GAC } \\
\text { identification } \\
\text { no. } \\
\text { (fig. 1) }\end{array}$} & \multicolumn{2}{|c|}{ Integrity score } & \multirow{2}{*}{$\begin{array}{c}\text { 303(d) } \\
\text { listed } \\
\text { segment }\end{array}$} \\
\hline & & $\begin{array}{l}\text { Stream } \\
\text { habitat }\end{array}$ & Biological & \\
\hline Big Creek in Big Creek scenic area/Sam Houston National Forest & BIGC0015 & 8 & 15 & -- \\
\hline Branch Creek at FM 1375 bridge & BRAN0011 & 7 & 17 & -- \\
\hline Buffalo Bayou at Eldridge Pkwy. & BUFF0005 & 10 & 13 & -- \\
\hline Buffalo Bayou at West Belt Dr. & BUFF3600 & 7 & 5 & -- \\
\hline Buffalo Bayou at Houston & BUFF4000 & 2 & 5 & -- \\
\hline Caney Creek near Willis & CANY0017 & 10 & 15 & -- \\
\hline Caney Creek near New Caney & CANY0020 & 10 & 19 & -- \\
\hline Cedar Bayou near Crosby & CEDR7500 & 6 & 14 & -- \\
\hline Cypress Creek west of I-45 and north of FM 1960 at Cypresswood & CYPR1324 & 7 & 17 & yes \\
\hline Cypress Creek at Kuykendahl Rd. bridge & CYPR1329 & 4 & 15 & yes \\
\hline Cypress Creek at Grant Rd. & CYPR8800 & 4 & 10 & yes \\
\hline East Fork San Jacinto River at FM 945 & EFSJ0016 & 7 & 19 & -- \\
\hline East Fork San Jacinto River near New Caney & EFSJ0200 & 10 & 17 & -- \\
\hline East Fork San Jacinto River on FM 2025 & EFSJ1237 & 11 & 18 & -- \\
\hline Greens Bayou at Mt. Houston Pkwy. & GREN0034 & 2 & 8 & yes \\
\hline Lake Creek at FM 149 & LAKE0012 & 6 & 19 & -- \\
\hline Lake Creek near Egypt & LAKE1367 & 10 & 18 & -- \\
\hline Langham Creek at Patterson Rd. & LANG0003 & 5 & 5 & -- \\
\hline Luce Bayou above Lake Houston near Huffman & LUCE1280 & 11 & 19 & -- \\
\hline Panther Creek at The Woodlands & PANT0040 & 10 & 19 & -- \\
\hline Spring Branch Creek at State 242/FM 2090 & SPRB0022 & 3 & 12 & -- \\
\hline Spring Creek at Riley Fuzzel & SPRI0023 & 6 & 14 & -- \\
\hline Spring Creek near Tomball & SPRI0024 & 8 & 17 & yes \\
\hline Spring Creek on Robert Cemetery Rd. & SPRI0027 & 10 & 15 & yes \\
\hline Spring Creek at Spring ( $\mathrm{I}-45$ bridge) & SPRI8500 & 6 & 11 & -- \\
\hline Walnut Creek near Magnolia & WALN0026 & 7 & 17 & -- \\
\hline West Fork San Jacinto River at State 30 & WFSJ0010 & 5 & 10 & -- \\
\hline West Fork San Jacinto River near Conroe at I-45 & WFSJ8000 & 10 & 12 & -- \\
\hline West Fork San Jacinto River above Lake Houston near Porter & WFSJ8090 & 6 & 22 & -- \\
\hline Willow Creek near Tomball & WILL8325 & 5 & 8 & -- \\
\hline White Oak Bayou at Bingle Rd. & WOAK1394 & 1 & 10 & yes \\
\hline
\end{tabular}

${ }^{1}$ Threatened or impaired water in Texas (Texas Natural Resource Conservation Commission, 1999).

were typical of the more urbanized drainage areas such as Greens Bayou (GREN0034) and White Oak Bayou (WOAK1394). These small scores are consistent with reaches that have been channelized for flood control, which has greatly simplified the channel. However, Buffalo Bayou at Houston (BUFF4000) and Langham Creek at Patterson Road (LANG0003), which have drainage areas that are urbanized but not extensively 


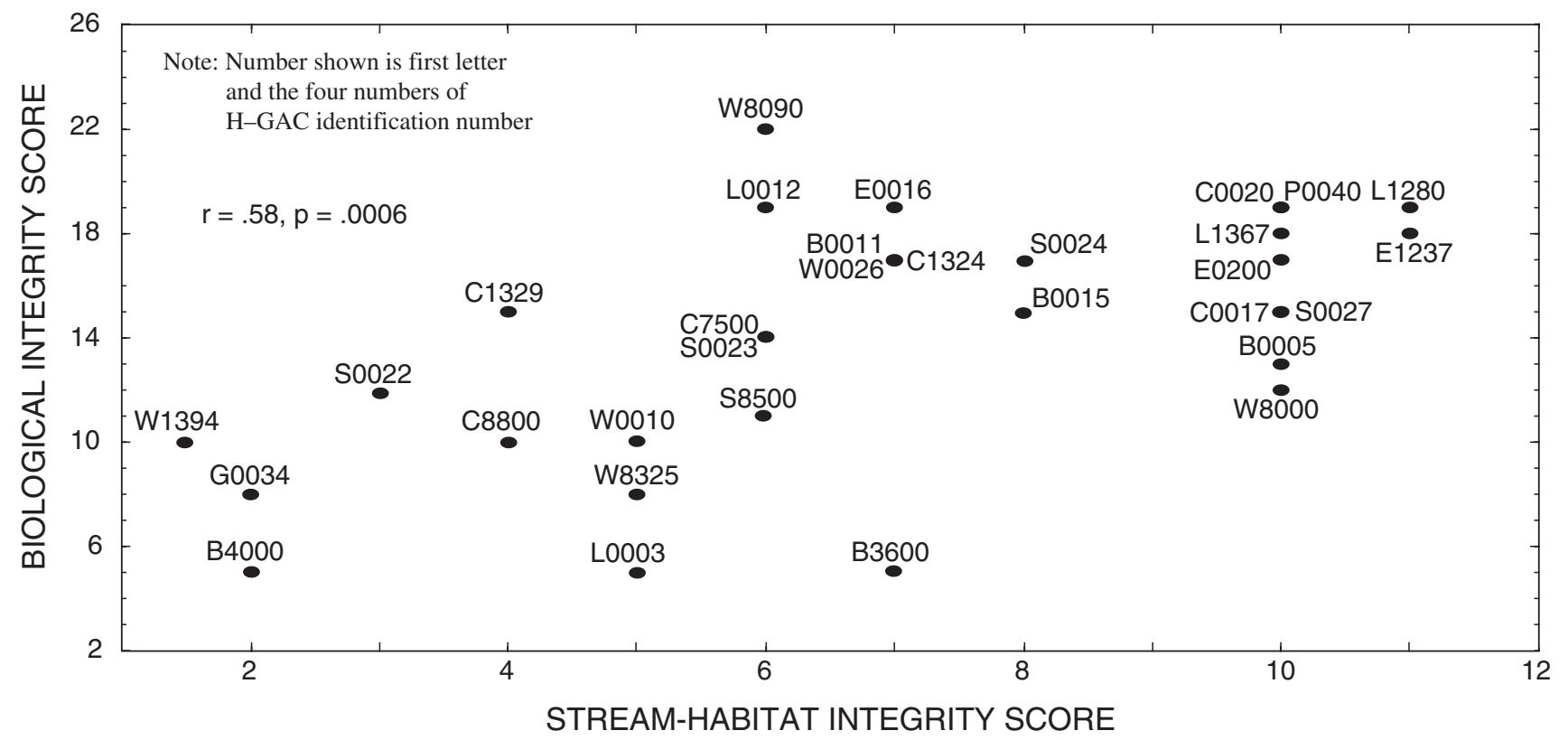

Figure 9. Correlation of stream-habitat integrity score with biological integrity score for selected reaches.

channelized, also had relatively small stream-habitat integrity scores.

The median biological integrity score computed for the seven reference reaches is 17 (fig. 10). The larger the structural index of a reach, generally the larger the frequency of in-channel woody debris such as leaf-packs and woody snags. These types of structures provide an energy base and substrate that can support a benthic aquatic insect community dominated by EPT taxa. The EPT in the streams of southeastern Texas are dominated by Ephemeroptera (mayflies) and Trichoptera (caddisflies) taxa. Many of the urban reaches, such as Langham Creek at Patterson Road (LANG003), are more susceptible to increased rates of runoff during a rainfall event that reduce the number of stable structures in the channel. These reaches also have less riparian and drainage-area sources to supply the stream with coarse organic material such as woody snags and leaves. Therefore, a more depauperate (or less developed) EPT assemblage in these urban reaches is not surprising.

Seven reaches in this study (table 7) are included in the State of Texas list of threatened or impaired waters, the State 303(d) list (Texas Natural Resource Conservation Commission, 1999). These reaches are listed as not meeting applicable aquatic-life use designations. Included on the 303(d) list are three
Cypress Creek reaches (CYPR1324, CYPR1329, and CYPR8800), one Greens Bayou reach (GREN0034), two Spring Creek reaches (SPRI0024 and SPRI0027), and one White Oak Bayou reach (WOAK1394). Cypress Creek and Spring Creek segments are listed for dissolved oxygen concentrations that are sometimes lower than the standard established to assure optimum conditions for aquatic life. Greens Bayou and White Oak Bayou are listed for exceedance of the applicable dissolved lead concentration established for the protection of aquatic life. The biological integrity scores for CYPR1324 and SPRI0024 equaled the median biological integrity reference-reaches score of 17 ; and the biological integrity scores for the other five 303(d) sites ranged from 8 for GREN0034 to 15 for CYPR1329 and SPRI0027. The habitat integrity score for SPRI0027 equaled the median habitat integrity reference-reaches score of 10; and the habitat integrity scores for the other six 303(d) sites ranged from 1 for WOAK1394 to 7 for CYPR1324.

The 303(d) listing process often is based solely on surrogates, such as dissolved oxygen and lead concentrations, in place of more direct aquatic life measures of community status. Studies that use direct measures of stream habitat and biological integrity compared to and collocated with the more traditional water-chemistry measures will help researchers, regulators, and water 

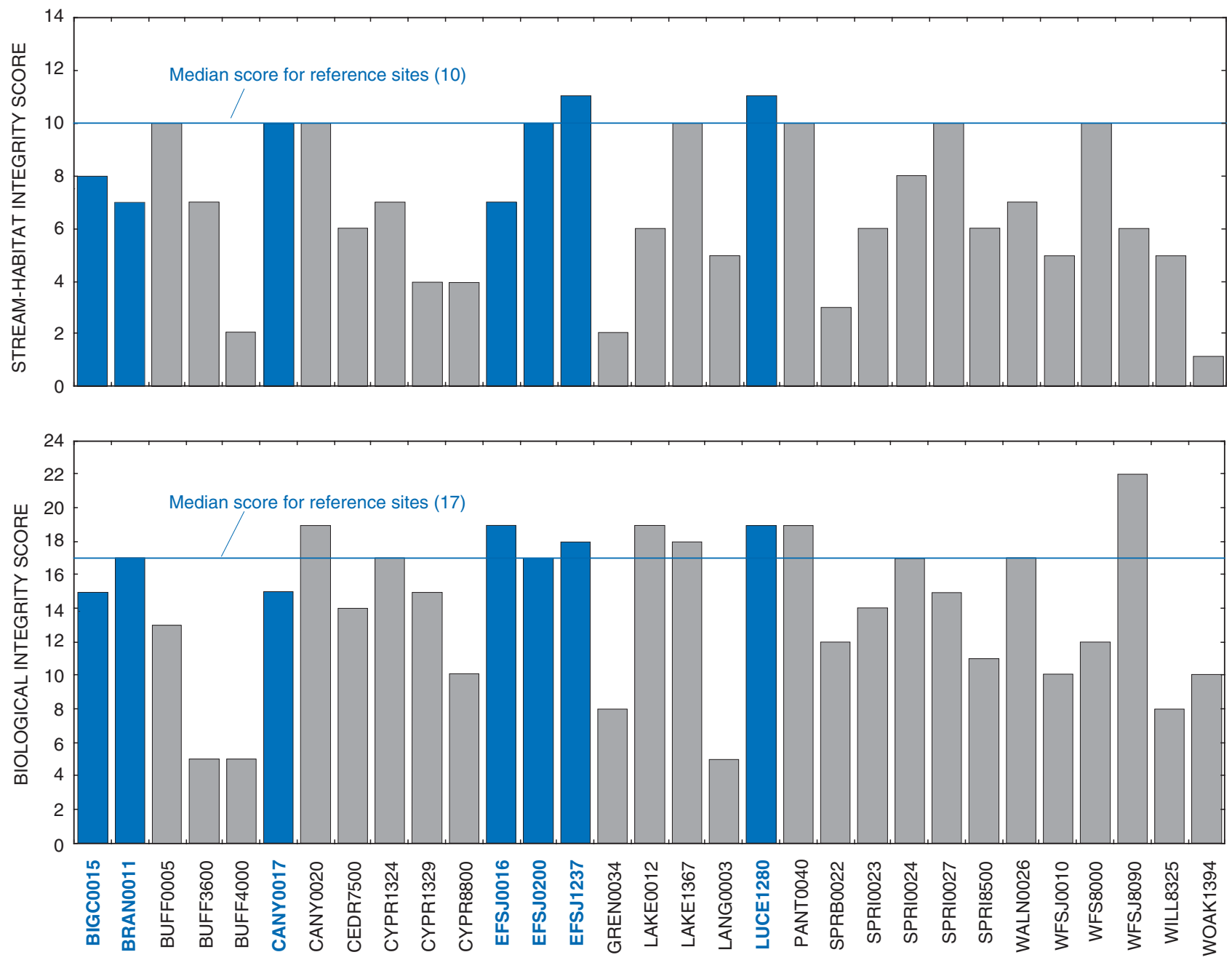

Figure 10. Stream-habitat and biological integrity scores compared to median integrity scores for reference sites.

managers by providing supplemental information that could help to support or refute the surrogate-based designations.

\section{Multiple-Regression Model to Predict Biological Integrity}

A multiple-regression model was developed to predict a biological integrity score for a reach on the basis of the input of several independent variables. The independent variables selected for the multipleregression model include percent forest land use in drainage area, number of people per square mile in the drainage area, and RCE maximum. These independent variables were selected because they can be obtained without field-intensive studies and can be used to predict the biological integrity of a stream reach without actually collecting and processing biological samples. The predicted biological integrity score can be compared to an actual score determined from biological samples collected from the reach, and the deviation of the actual score from the predicted or expected score can be used to interpret the degree of impairment to reach biota. However, an independent dataset of integrity scores from reaches outside the group of reaches used in this study is needed to test the validity of the model. Additional above-tidal reaches within the San Jacinto River Basin and possibly adjacent river basins such as the Trinity and Neches could be selected to test the model.

A statistically significant multiple regression $(r=0.69, F(3,27)=8.04, p=0.0006)$ was determined using percent forest land use, people per square mile, 
and RCE maximum for each reach as independent variables. The biological integrity score was used as the dependent variable. The multiple-regression equation is:

\begin{tabular}{|c|c|c|c|}
\hline $\begin{array}{l}Y=5.73 \\
\text { biolog- } \\
\text { ical in- }\end{array}$ & $\begin{array}{c}0.065 \\
(\mathrm{RCE} \\
\text { maxi- } \\
\text { mum) }\end{array}$ & $\begin{array}{c}+6.32 \\
\text { (percent } \\
\text { forest }\end{array}$ & $\begin{array}{c}-0.002 \\
\text { (people } \\
\text { per square }\end{array}$ \\
\hline
\end{tabular}

\section{SUMMARY}

During 1997-98 the USGS, in cooperation with the H-GAC, collected stream-habitat and benthic macroinvertebrate data for 31 above-tidal sites (reaches) in the H-GAC service area near Houston, Texas. The 31 reaches (30 in the San Jacinto River Basin and 1 in the adjacent Trinity River Basin) were screened from a pool of 56 reaches. Stream-habitat, land-use and population, and benthic aquatic insect metrics were determined for the 31 reaches.

A multivariate statistical procedure, principal components analysis (PCA), was used to determine the stream-habitat, land-use and population, and aquatic insect variables that are strongly intercorrelated and that explain the greatest variation between reaches. These analyses indicated that:

- The variables reach structural index and RCE explained a significant proportion of the betweenreach variability.

- Percent forest land use of the above-reach drainage area and population density (number of people per square mile) of the drainage area explained a significant proportion of between-reach variability.

- The aquatic insect variables percent EPT taxa, Hilsenhoff's biotic index, number of taxa, Simpson's heterogeneity index, and percent Oligochaeta and Chironomidae explained a significant proportion of between-reach variability.

Stream-habitat and biological integrity scores were computed for each of the 31 reaches. The PCAselected stream-habitat variables-reach structural index and RCE maximum-were used to compute the stream-habitat integrity score; the aquatic insect variables-percent EPT taxa, number of taxa, Hilsenhoff's biotic index, and percent Chironomidae-were used to compute the biological integrity score. Comparison of these indices indicated:
- Reaches generally had larger stream-habitat integrity scores in drainage areas that were heavily forested and had fewer people per square mile.

- Larger biological integrity scores were significantly correlated with larger stream-habitat integrity scores; urban reaches generally had more simplified stream-habitat conditions and smaller biological integrity scores.

- Seven reaches, BIGC0015, BRAN0011, CANY0017, EFSJ0016, EFSJ0200, EFSJ1237, and LUCE1280, were selected as reference reaches on the basis of high stream-habitat integrity and high biological integrity. The reference-reaches median biological integrity score of 17 was equaled by one Cypress Creek reach and one Spring Creek reach that are on the State of Texas list of threatened or impaired waters (the State 303(d) list) for not meeting their aquatic life use designation. This indicates that direct measures of biological integrity could provide supplemental information to support or refute surrogate-based designations such as the State 303(d) list.

A statistically significant multiple-regression model was developed that uses percent forest land use, RCE maximum, and number of people per square mile as variables to predict the biological integrity score for a reach. Data for these independent variables can be obtained without field-intensive studies. The deviation of a score based on biological sampling from the predicted score can be used to interpret the degree of impairment to a reach's biota. An independent dataset from reaches outside the group of reaches used in this study is needed to test the validity of the model.

\section{REFERENCES CITED}

Barbour, M.T., Gerritsen, J., Snyder, B.D., and Stribling, J.B., 1997, Revision to rapid bioassessment protocols for use in streams and rivers-Periphyton, benthic macroinvertebrates, and fish: U.S. Environmental Protection Agency, Office of Water, EPA 841-D-97-002.

Cuffney, T.F., Gurtz, M.E., and Meador, M.R., 1993, Methods for collecting benthic invertebrate samples as part of the National Water-Quality Assessment Program: U.S. Geological Survey Open-File Report 93-406, 66 p.

Gurtz, M.E., 1994, Design of biological components of the National Water-Quality Assessment (NAWQA) Program-Chapter 15, in Loeb, S.L., and Spacies, A., eds., 
Biological monitoring of freshwater ecosystems: Boca Raton, Fla., Lewis Publishers, p. 323-354.

Hilsenhoff, W.L., 1987, An improved biotic index of stream pollution: Great Lakes Entomology, v. 20, p. 31-39.

Ludwig, J.A., and Reynolds, J.F., 1988, Statistical ecologyA primer of methods and computing: New York, Wiley, $337 \mathrm{p}$.

Meador, M.R., Hupp, C.R., Cuffney, T.F., and Gurtz, M.E., 1993, Methods for characterizing stream habitat as part of the National Water-Quality Assessment Program: U.S. Geological Survey Open-File Report 93-408, 48 p. Moring, J.B., Rosendale, J.C., Ansley, S.P., and Brown, D.W., 1998, Fish, benthic macroinvertebrate, and stream habitat data from the Houston-Galveston Area Council Service Area, Texas, 1997-98: U. S. Geological Survey Open-File Report 98-658, 116 p.

Omernick, J.N., 1987, Ecoregions of the conterminous United States: Annals of the Association of American Geographers, v. 77, p. 118-125.

Petersen, R.C., 1992, The RCE_A riparian, channel, and environmental inventory for small streams in the agricultural landscape: Freshwater Biology, v. 27, p. 295-306.

Reynoldson, T.B., Norris, R.H., Resh, V.H., Day, K.E., and Rosenberg, D.M., 1997, The reference condition-A comparison of multimetric and multivariate approaches to assess water-quality impairment using benthic macroinvertebrates: Journal of the North American Benthological Society, v. 16, no. 4, p. 833-853.
STATISTICA, 1999, STATISTICA for Windows and Windows 95/98/NT: Tulsa, Okla., Statsoft, Inc.

Texas Natural Resource Conservation Commission, 1999, State of Texas 1999 Clean Water Act Section 303(d) list and schedule for development of total maximum daily loads (TMDLs): SFR-58/99, accessed November 9, 2000, at URL http://www.tnrcc.state.tx.us/admin/topdoc/sfr/058-99/

2000, The Texas Clean Rivers Program: Accessed September 20,2000, at URL http://www.tnrcc.state.tx.us/water/quality/data/wmt/ tcrp.html\#how_crp

U.S. Census Bureau, 2000, Land area, population, and density for states and counties: Accessed September 20, 2000, at URL

http://www.census.gov/population/censusdata/ 90den_stco.txt

Vannote, R.L., Minshall, G.W., Cummins, K.W., Sedell, J.R., and Cushing, C.E., 1980, The river continuum concept: Canadian Journal of Fisheries and Aquatic Sciences, v. 37, p. 130-137.

Wang, L., Simonson, T.W., and Lyons, J., 1996, Accuracy and precision of selected stream habitat estimates: North American Journal of Fisheries Management, v. 16, p. 340-347.

Ward, J.V., 1992, Aquatic insect ecology-1. Biology and habitat: New York, Wiley, 438 p.

Zar, J.H., 1984, Biostatistical analysis (2d ed.): Englewood Cliffs, N.J., Prentice-Hall, 718 p. 
District Chief

U.S. Geological Survey

8027 Exchange Dr.

Austin, TX 78754-4733 